\title{
Data Quality Objectives Supporting Radiological Air Emissions Monitoring for the PNNL Site
}
JM Barnett
BG Fritz
KM Meier
TM Poston
SF Snyder
K Rhoads

May 2010

\section{Pacific Northwest}

NATIONAL LABORATORY

Proudly Operated by Battelle Since 1965 


\title{
DISCLAIMER
}

This report was prepared as an account of work sponsored by an agency of the United States Government. Neither the United States Government nor any agency thereof, nor Battelle Memorial Institute, nor any of their employees, makes any warranty, express or implied, or assumes any legal liability or responsibility for the accuracy, completeness, or usefulness of any information, apparatus, product, or process disclosed, or represents that its use would not infringe privately owned rights. Reference herein to any specific commercial product, process, or service by trade name, trademark, manufacturer, or otherwise does not necessarily constitute or imply its endorsement, recommendation, or favoring by the United States Government or any agency thereof, or Battelle Memorial Institute. The views and opinions of authors expressed herein do not necessarily state or reflect those of the United States Government or any agency thereof.

\author{
PACIFIC NORTHWEST NATIONAL LABORATORY \\ operated by \\ BATTELLE \\ for the \\ UNITED STATES DEPARTMENT OF ENERGY \\ under Contract DE-ACO5-76RL01830
}

Printed in the United States of America
Available to DOE and DOE contractors from the
Office of Scientific and Technical Information,
P.O. Box 62, Oak Ridge, TN 37831-0062;
ph: (865) 576-8401
fax: (865) 5765728
email: reports@adonis.osti.gov

\author{
Available to the public from the National Technical Information Service, \\ U.S. Department of Commerce, 5285 Port Royal Rd., Springfield, VA 22161 \\ ph: (800) 553-6847 \\ fax: (703) 605-6900 \\ email: orders@nits.fedworld.gov \\ online ordering: http://www.ntis.gov/ordering.htm
}




\title{
Data Quality Objectives Supporting Radiological Air Emissions Monitoring for the PNNL Site
}

\author{
JM Barnett \\ BG Fritz \\ KM Meier \\ TM Poston \\ SF Snyder \\ K Rhoads
}

May 2010

Prepared for

the U.S. Department of Energy

under Contract DE-AC05-76RL01830

Pacific Northwest National Laboratory

Richland, Washington 99352 


\section{Summary}

Pacific Northwest National Laboratory (PNNL) is in the process of developing a radiological air monitoring program for the PNNL Site that is distinct from that of the nearby Hanford Site. Radiological emissions at the PNNL Site result from Physical Sciences Facility (PSF) major emissions units. A team was established to determine how the PNNL Site would meet federal regulations and address guidelines developed to monitor air emissions and estimate offsite concentrations of radioactive materials. The result is a program that monitors the impact to the public from the PNNL Site.

The team used the emission unit operation parameters and Hanford Site meteorological data as well as information from the PSF Potential-to-Emit documentation and Notices of Construction submitted to the Washington State Department of Health (WDOH). The locations where environmental monitoring stations would successfully characterize emissions from the three PSF buildings with major emission units were determined from these data.

Considering any constraints either by location, occupancy, and the availability of existing monitoring stations, the team selected to co-locate with two existing monitoring stations NNW and N of the PNNL Site and initiated a new third monitoring station, SSE of the PNNL Site near the PNNL National Security Building (NSB). The existing stations are part of the air surveillance network operated by the Surface Environmental Surveillance Project for the U.S. Department of Energy’s Hanford Site.

This DQO report also discusses the sampling and analysis requirements for the PNNL Site air samples and how existing Hanford Site monitoring program results could be used.

This document of Data Quality Objectives (DQOs) was prepared based on the U.S. Environmental Protection Agency (EPA) Guidance on Systematic Planning Using the Data Quality Objectives Process, EPA, QA/G4, 2/2006 (EPA 2006) as well as several other published DQOs. 



\section{Acronyms and Abbreviations}

\begin{tabular}{ll} 
CAP-88 & Clean Air Act Assessment Package-1988 \\
CAP88-PC & Clean Air Act Assessment Package 1988-Personal Computer \\
cfm & Cubic Feet Per Minute \\
CFR & Code of Federal Regulations \\
DOE & U.S. Department of Energy \\
DOE-SC & U.S. Department of Energy-Office of Science \\
DQO & Data Quality Objectives \\
EMSL & Environmental Molecular Sciences Laboratory \\
EPA & U.S. Environmental Protection Agency \\
HEIS & Hanford Environmental Information System \\
MDA & Minimum Detectable Activity \\
MEI & Maximally Exposed Individual \\
mrem & Millirem \\
NESHAP & National Emission Standards for Hazardous Air Pollutants \\
NOC & Notice of Construction \\
NRM & Not Routinely Measured \\
NSB & National Security Building (PNNL) \\
PNNL & Pacific Northwest National Laboratory \\
PNSO & (U.S. Department of Energy) Pacific Northwest Site Office \\
PSF & Physical Sciences Facility \\
PTE & Potential-to-Emit \\
QA & Quality Assurance \\
RCRA & Resource Conservation and Recovery Act \\
RDL & Required Detection Limit \\
SESP & Surface Environmental Surveillance Project \\
TEDE & Total Effective Dose Equivalent \\
WAC & Washington Administrative Code \\
WDOH & (State of) Washington Department of Health \\
X/Q & Chi-over-Q \\
\hline
\end{tabular}




\section{Definitions}

Acute Release - A short-duration release of a radioactive air pollutant with a potentially significant dose consequence.

Chi-over-Q (X/Q) - Concentration of a radioactive material in air at a downwind location, normalized by the release rate of the material from the source facility. In this document, Chi-over-Q is expressed in units of sec $/ \mathrm{m}^{3}$ (radioactivity per cubic meter per radioactivity released per second).

Chronic Release-The nearly continuous release of small quantities of radioactive air pollutants from an emission unit over a period of at least 3 months.

Diffuse Source (nonpoint source) - As applied in Washington Administrative Code (WAC) 246-247 (18) “... a location at which radioactive air emissions originate from an area, such as contaminated ground above a near-surface waste disposal unit, whose extent may or may not be welldefined."

Emission Unit—As applied in Washington Administrative Code (WAC) 246-247-030[10]:

“... any single location that emits or has the potential to emit airborne radioactive material. This may be a point source, nonpoint source, or source of fugitive emissions.”

Fugitive Emissions-As applied in Washington Administrative Code (WAC) 246-247-030[12]:

“...radioactive air emissions which do not and could not reasonably pass through a stack, vent, or other functionally equivalent structure, and which are not feasible to directly measure and quantify.”

Major Emission Unit-An emission unit having the potential to emit radionuclides that could result in a dose to the maximally exposed individual exceeding one percent of the $10 \mathrm{mrem} / \mathrm{year}$ dose standard in 40 CFR Part 61, Subpart H (i.e., greater than $0.1 \mathrm{mrem} /$ year). Major sources are subject to the continuous monitoring requirements of 40 CFR Section 61.93.

Maximally Exposed Individual (MEI) - For the purpose of this DQO report, a maximally exposed individual is a hypothetical member of the public residing near the Pacific Northwest National Laboratory (PNNL) Site who, by virtue of location and living habits, could receive the highest potential radiation dose from radioactive effluents released from the PNNL Site during a calendar year. The MEI dose calculation can be either prospective or retrospective in nature. A prospective MEI location is based on maximum potential radionuclide emissions (the "potential-to-emit”) and long-term meteorological data. The retrospective MEI location uses actual emissions and meteorological data applicable to the year for which the evaluation is performed. Emissions affecting the MEI may originate from point sources (i.e., actively ventilated stacks and vents) as well as from fugitive and diffuse sources (such as contaminated soil areas or other facilities that are not actively ventilated). Compliance with federal and state dose standards is determined by the retrospective MEI dose for a specific calendar year.

Millirem (mrem) — A unit of radiation total effective dose equivalent (TEDE) based on the potential for impact on human cells.

Minor Emission Unit-An emission unit having the potential to emit radionuclides that would not result in a dose exceeding one percent of the $10 \mathrm{mrem} /$ year dose standard in 40 CFR Part 61, Subpart $\mathrm{H}$ 
(i.e., less than $0.1 \mathrm{mrem} / \mathrm{year}$ ) to a maximally exposed individual. Minor sources are subject to the periodic confirmatory measurement requirements of 40 CFR Section 61.93.

Notice of Construction (NOC) — As defined in WAC 246-247-030[19]: “... an application submitted to the [Washington State Department of Health] by an applicant that contains information required by WAC 246-247-060 for proposed construction or modification of a registered emission unit(s), or for modification of an existing, unregistered emission unit(s)."

Potential-to-Emit (PTE) — Radionuclide emissions estimated for purposes of permitting a new or modified emission unit. As defined in WAC 246-247-030(21): “...the rate of release of radionuclides from an emission unit based on the actual or potential discharge of the effluent stream that would result if all abatement control equipment did not exist, but operations are otherwise normal.”

Total effective dose equivalent (TEDE) - The sum of the dose equivalent (for external exposures) and the committed effective dose equivalent (for internal exposures). In this document, TEDE is expressed in units of millirem. 



\section{Contents}

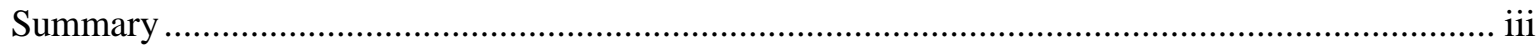

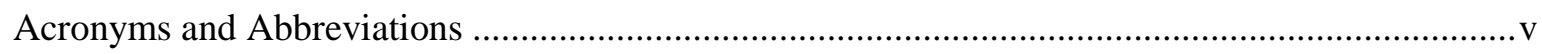

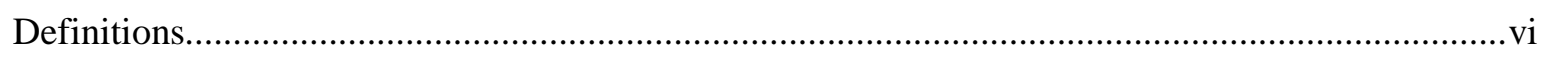

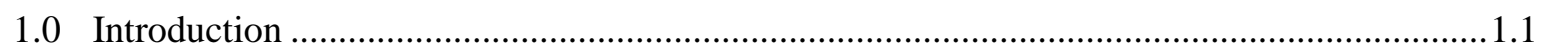

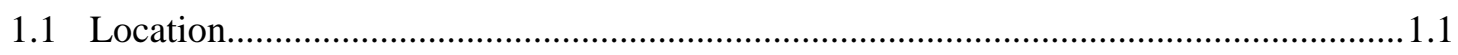

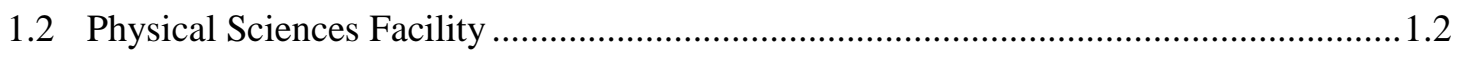

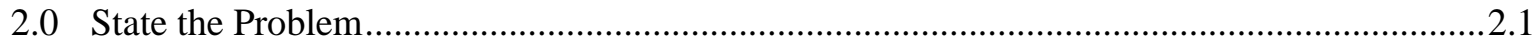

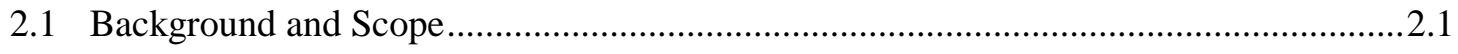

2.2 Applicable Regulatory Requirements .....................................................................2.2

2.3 Problem Statement and Preliminary Data ................................................................... 2.3

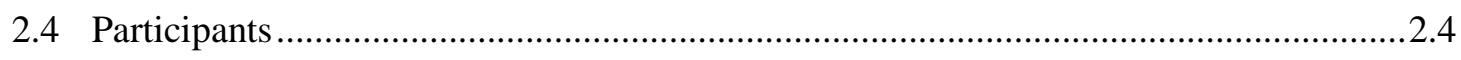

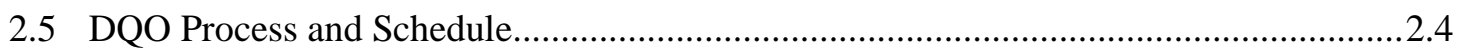

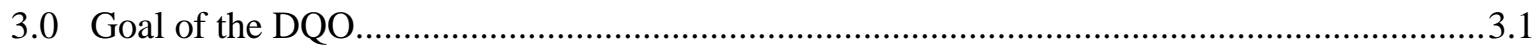

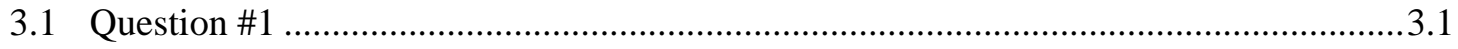

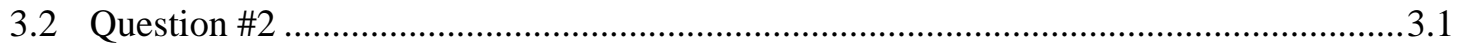

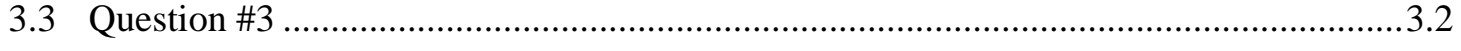

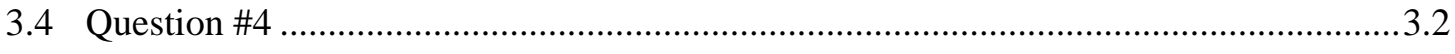

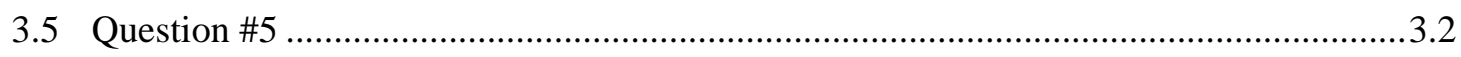

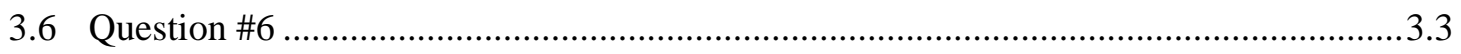

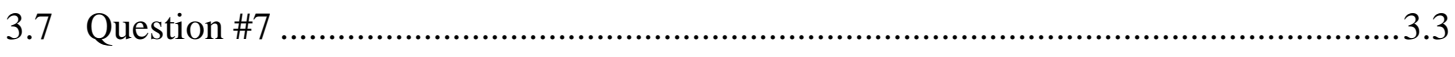

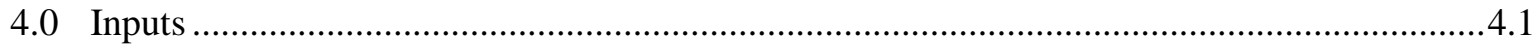

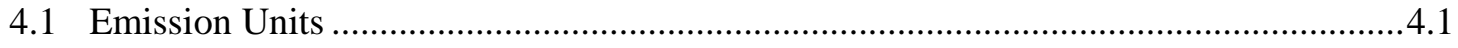

4.2 List of Radionuclides-of-Concern ................................................................................... 4.2

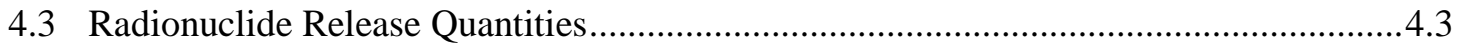

4.4 Major Emission Unit Characteristics ......................................................................4.4

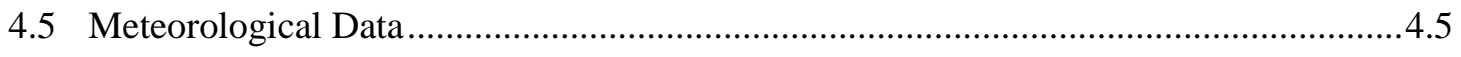

4.6 Air Dispersion Modeling, CAP88-PC Model .............................................................. 4.6

4.7 MEI Exposure Characteristics............................................................................. 4.7

4.8 Relevant Maximum Air Concentration Location(s)....................................................... 4.7

4.9 Adequate Monitoring Program.................................................................................... 4.11

4.10 Existing Hanford Site Monitoring Station Locations................................................... 4.11

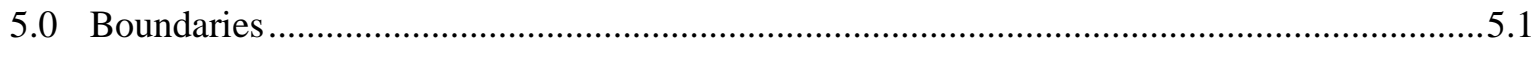

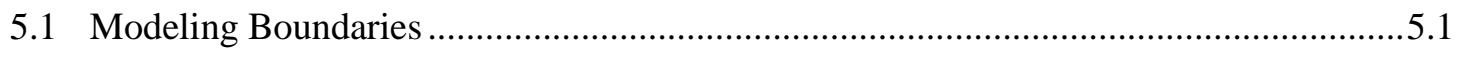

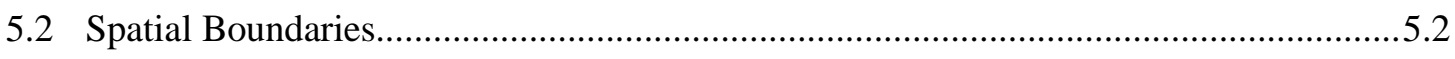




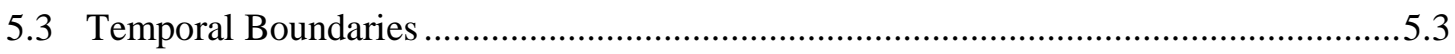

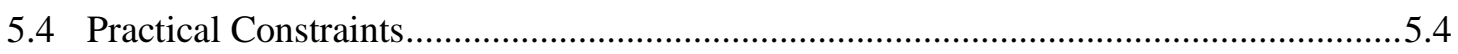

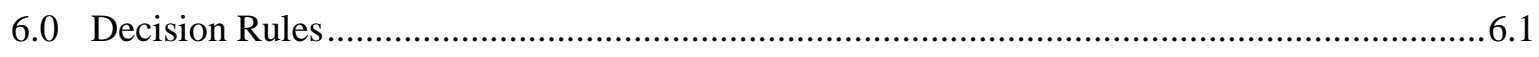

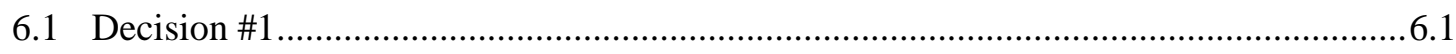

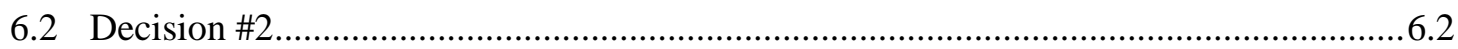

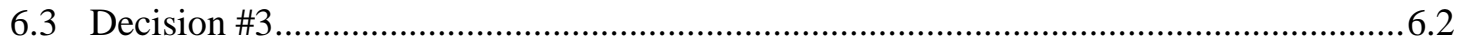

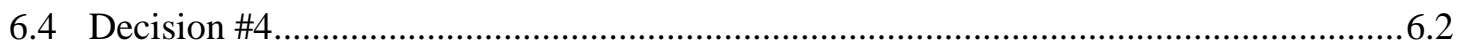

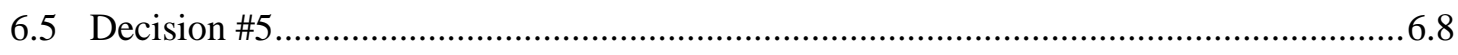

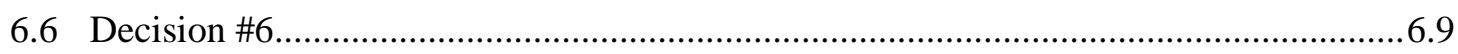

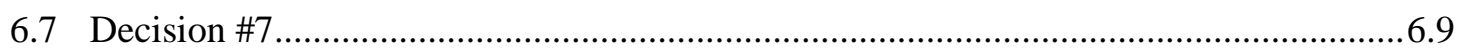

7.0 Decision Error Assessment...............................................................................................

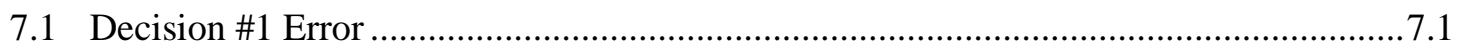

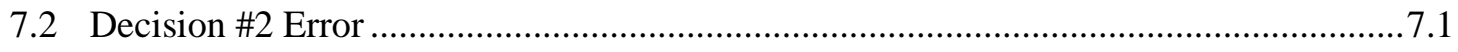

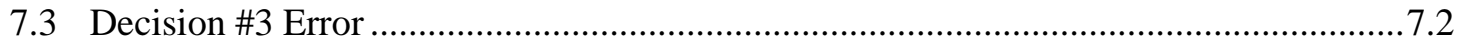

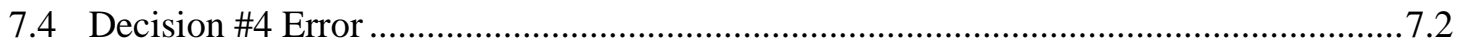

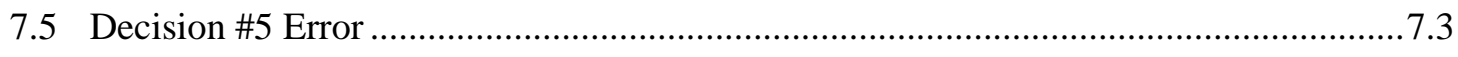

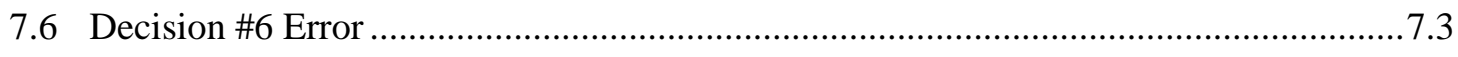

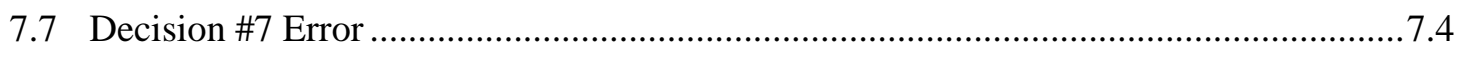

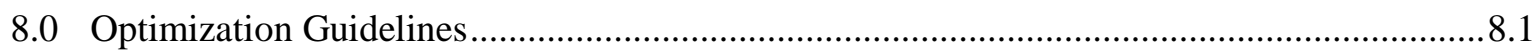

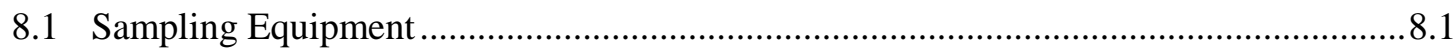

8.2 Analytical Detection Limits .................................................................................. 8.1

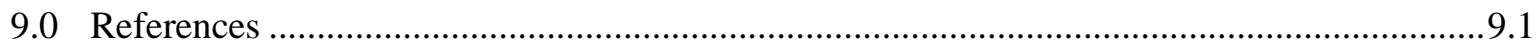

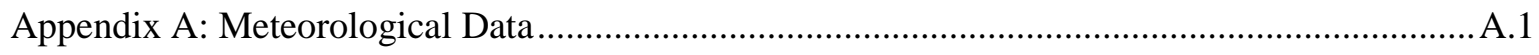

Appendix B: Chi-over-Q Tables ...................................................................................... B. 


\section{Figures}

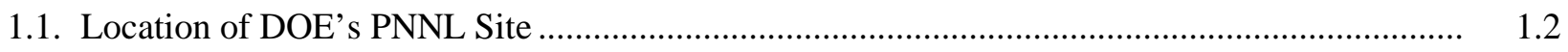

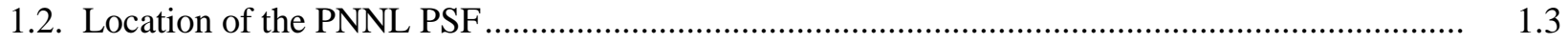

2.1. Existing Monitoring Stations North of the PNNL Site and MEI ( $\star$ ) Site of WDOH

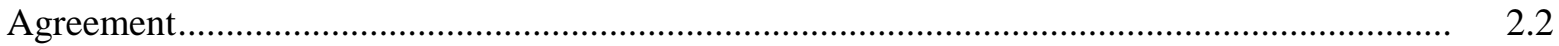

4.1. X/Q Values $\left(\mathrm{s} / \mathrm{m}^{3}\right)$ for Indicated Location for Five Distances from PSF 3410 Building............. $\quad 4.9$

4.2. Air Concentration Ratios of the Indicated Location to that of a Proposed Station Location (480 m SSE of 3410 Building) when greater than 0.5 or at the Fenceline Location

4.3. Boundary Visual with Yellow Lines Indicating Centerline Compass Directions from PSF

5.1. Offsite Buildings with Potential Receptors................................................................................. 5.3

6.1. SE, SSE, and S Sectors from Emission Units .........................................................................

6.2. Locations Relative to the 3410 Building that Are at Least $65 \%$ of the Maximum Air Concentration

6.3. Locations Relative to the 3420 Building that Are at Least $65 \%$ of the Maximum Air Concentration

6.4. Locations Relative to the 3430 Building that Are at Least $65 \%$ of the Maximum Air Concentration.

6.5. Overlap of the Three PSF Facility “65\% Regions” of the Previous Three Figures..... 6.6

6.6. Air Concentration Ratios of Indicated Location to the Maximum Location (480 m SSE of 3410) when $65 \%$ or Greater AND Beyond the PNNL Site Fenceline...

6.7. Circle Indicates the Location of the Proposed Monitoring Station (480 m SSE of 3410)......

6.8 


\section{Tables}

4.1. Radionuclides of Interest: 3410 Building-Materials Science and Technology Laboratory ..4.3

4.2. Radionuclides of Interest: 3420 Building-Radiation Detection Laboratory..........................4.3

4.3. Radionuclides of Interest: 3430 Building-Ultra-Trace Laboratory …..................................4.3

4.4. Unabated Release Estimates for Major Emission Units ......................................................4.4

4.5. Major and Minor Emission Unit Release Impact Comparison .............................................4.4

4.6. Major Emission Unit Operation Parameters ........................................................................ 4.5

4.7. Average Frequency of Wind Direction for the 300 Area Station (1983 through 2006) ..........4.6

4.8. Radionuclides to Be Monitored at the PNNL Site ............................................................11

5.1. Potential Receptor Locations for Radioactive Air Emissions from PNNL Site Major

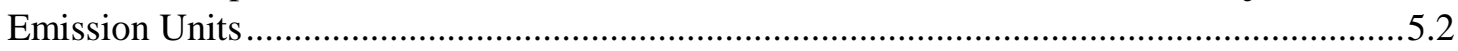

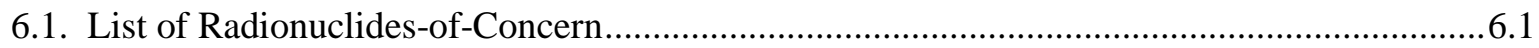

7.1. Chi-over-Q values from All Major Emission Units for the Proposed Location ......................7.3

8.1. Analytical Detection Limit Comparison to Notification Values..............................................8.3 


\subsection{Introduction}

This Data Quality Objectives (DQOs) report addresses the radiological air quality requirements and environmental monitoring needs for the Pacific Northwest National Laboratory (PNNL) Site, which is a research facility under the oversight of the U.S. Department of Energy's Office of Science (DOE-SC), Pacific Northwest Site Office (PNSO). For regulatory purposes, it is separate from the adjacent Hanford Site, which is under the oversight of the DOE Office of Environmental Management, Richland Operations Office. The approximately 350-acre PNNL Site (see Figure 1.1) consists of the Environmental Molecular Science Laboratory (EMSL) and the Physical Sciences Facility (PSF), which is located north of EMSL. The PSF is a complex of five research laboratories and other supporting facilities on the PNNL Site that replaces existing research and development space currently occupied by PNNL in the Hanford Site 300 Area. The reason for the DQO format used for this report is provided in Section 2.1.

DOE facilities are required to demonstrate compliance with the Clean Air Act National Emission Standards for Hazardous Air Pollutants (NESHAP) for radionuclides, as published in the 1989 amendments to Title 40 Code of Federal Regulations (CFR) Part 61, Subpart H, "National Emission Standards for Emissions of Radionuclides Other Than Radon From Department of Energy Facilities.” The U.S. Environmental Protection Agency (EPA) is the federal agency tasked with oversight and implementation of the regulations. EPA has delegated regulatory authority to the Washington State Department of Health (WDOH) for facilities within Washington State.

The WDOH establishes regulations for radionuclide air emissions in the Washington Administrative Code (WAC) Chapter 246-247, "Radiation Protection - Air Emissions” and adopts by reference the standards and approved methods specified in 40 CFR Part 61, Subpart H. Additional Washington State Department of Ecology regulations are found in WAC 173-480, “Ambient Air Quality Standards and Emission Limits for Radionuclides.” Additional federal and state requirements for environmental monitoring programs applicable to this DQO report are summarized in Section 2.2. These regulations are not intended to be applied to high-level or acute (short-term) emissions from accidents, and therefore, the discussions and conclusions in this document are limited to routine emissions characterized as chronic releases (occurring at substantially the same rate over time).

\subsection{Location}

PNNL is a DOE research facility operated by Battelle-Pacific Northwest Division in the north part of Richland, Washington. The current PNNL Campus (see Figure 1.1) consists of:

- Battelle-owned facilities,

- Leased facilities on Battelle-owned land,

- DOE-owned facilities in the Hanford Site 300 area, ${ }^{\text {(a) }}$

- other leased facilities, and

- DOE-owned facilities within the PNNL Site. ${ }^{\left({ }^{b}\right)}$

(a) The 300 Area facilities are managed under the DOE Office of Environmental Management.

(b) The PNNL Site facilities are managed under the DOE-SC. 


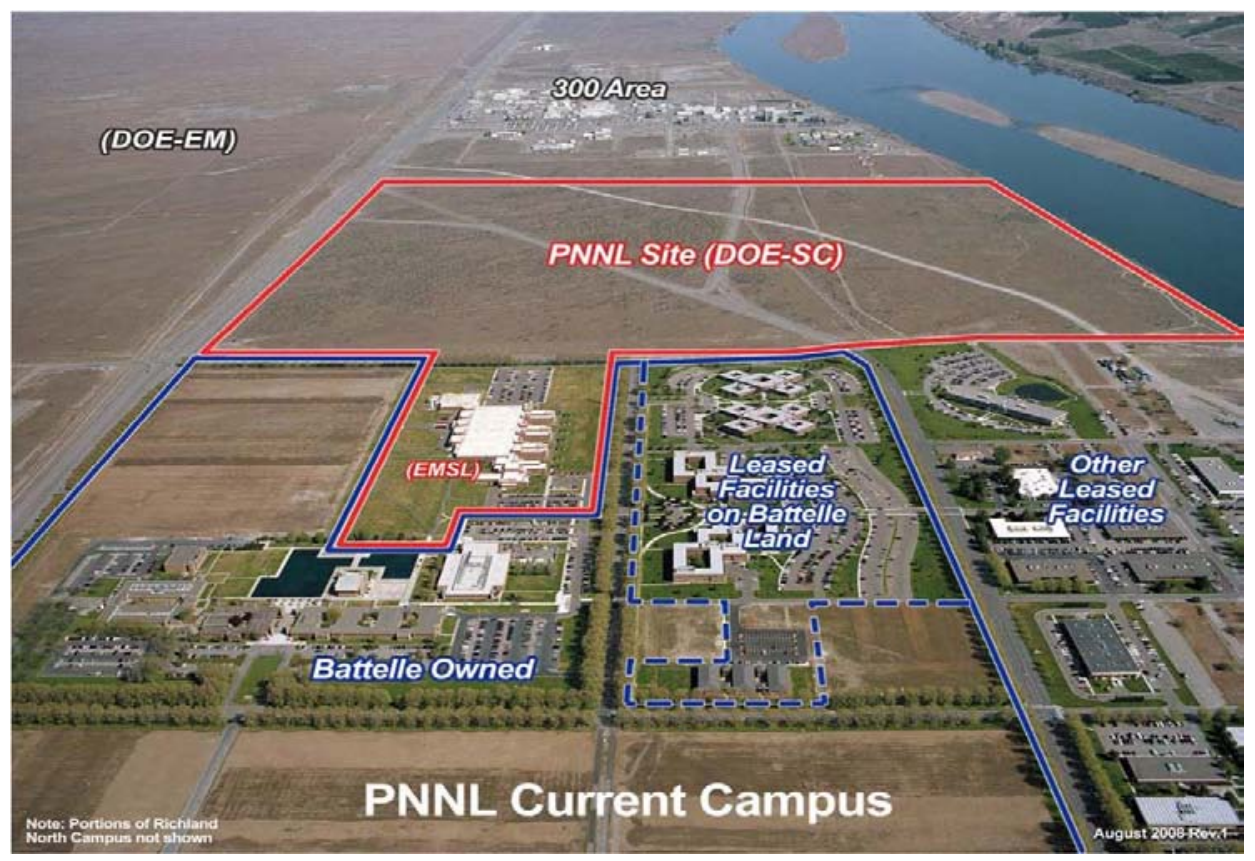

Figure 1.1. Location of DOE’s PNNL Site

The PSF (see Figure 1.2) consists of the following buildings (with indication of their major and minor radionuclide emission units or fugitive release sites):

- 3410—Materials Sciences and Technology Laboratory (major and possible minor)

- 3420—Radiation Detection Laboratory (major and minor)

- 3425-Underground Laboratory (fugitive)

- 3430-Ultra-Trace Laboratory (major and minor)

- 3440 - Large Detector Laboratory (possible minor).

The EMSL facility, the only other facility on the PNNL Site, has been exempted from permitting and is allowed to conduct work with volumetrically released materials and limited non-dispersible materials released from radiological controls. EMSL is, however, a registered emission unit with WDOH.

\subsection{Physical Sciences Facility}

An emission unit as defined by WDOH is any single location that emits or has the potential to emit airborne radioactive material. This may be a point source, nonpoint source, or source of fugitive emissions. Emission units are categorized for regulatory oversight by their potential radiological release impacts as major or minor emission units. The 3410, 3420, and 3430 Buildings will each have a major emission unit where the term major indicates there is the potential for radioactive air emissions resulting in a dose to the maximally exposed individual (MEI) of $\geq 0.1 \mathrm{mrem} / \mathrm{yr}$. There are also minor emission units associated with the 3420, 3425, 3430, and potentially the 3410 and 3440 Buildings where the term minor indicates the potential for radioactive air emissions resulting in a dose to the MEI that is $<0.1 \mathrm{mrem} / \mathrm{yr}$. 


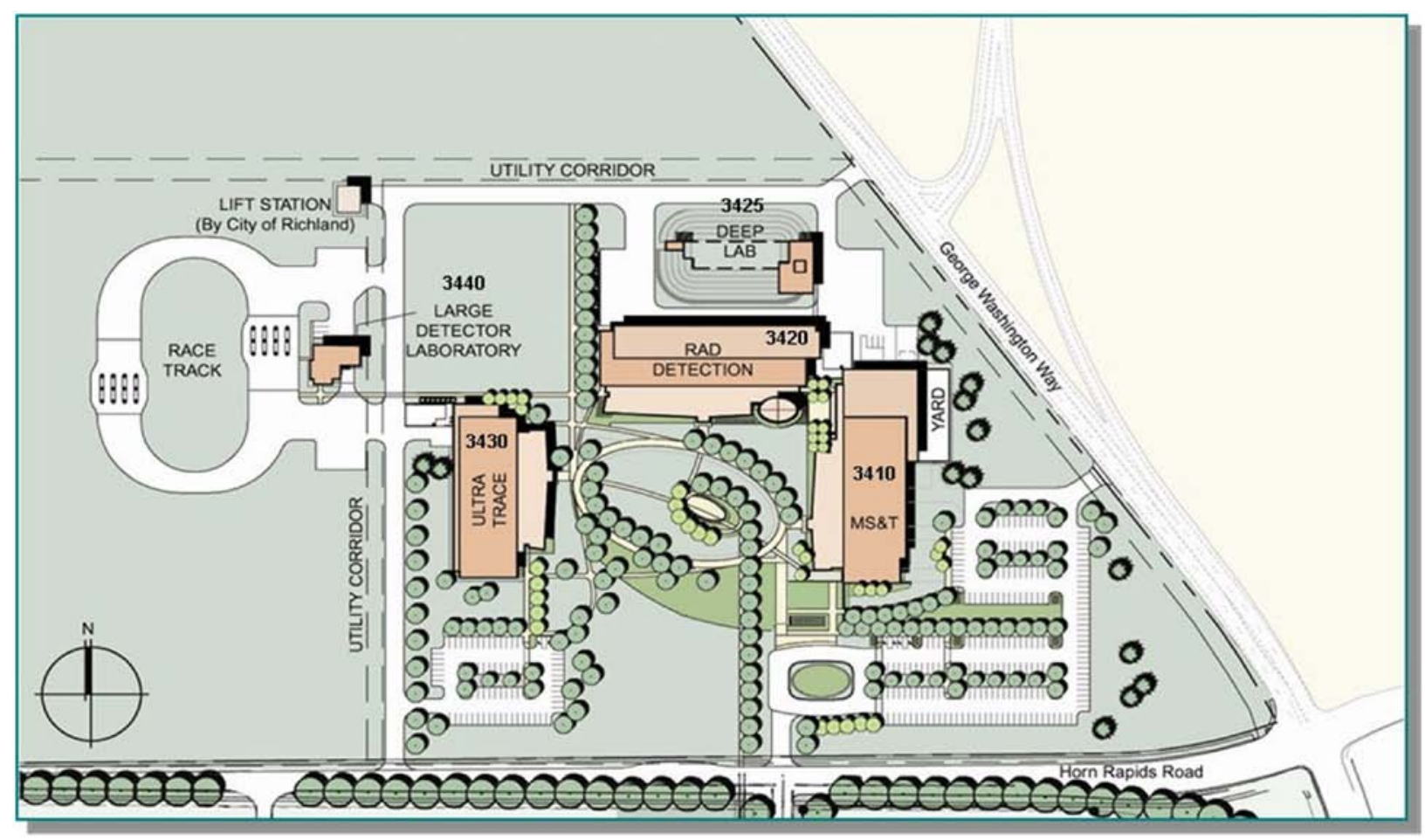

Figure 1.2. Location of the PNNL PSF 


\subsection{State the Problem}

Chapter 2.0 of this DQO report describes the problem (also called the primary study question) and discusses the preliminary data needed to answer the study question. In addition, this chapter discusses the DQO team, available resources, and schedule for completion of the DQO report.

\subsection{Background and Scope}

At the PNSO-WDOH interface meeting of November 12, 2008, WDOH indicated that the PNNL would need to establish an environmental monitoring program for the PNNL Site. WDOH stated that the agency was evaluating types of environmental monitoring that would need to be put in place. This was the first cooperative documented meeting between PNSO, WDOH, and PNNL where environmental monitoring was discussed as a condition of operation of the PNNL Site under a radioactive air emissions license. During calendar year 2009, the parties continued to discuss the various options for an environmental monitoring program and its implementation for the PNNL Site. In December 2009, WDOH indicated in the draft site license that a DQO process would be required to develop the environmental air monitoring program for the PNNL Site. In subsequent meetings with WDOH, it was agreed that during the interim, two environmental continuous monitoring stations (also referred to as sampling hutches) would be sufficient to demonstrate low emissions (see Figure 2.1). The two existing stations are located to the N and NNW of the PSF, and a new station is proposed in the vicinity of the MEI location south-southeast of the PNNL Site. Figure 2.1 indicates the locations of two existing sampling hutches (Monitoring Station 1 is located near the Hanford Site’s 361 Building; Monitoring Station 2 is also on the Hanford Site and is located near the South Gate Exit of the 300 Area), and a star marks the location of the maximum individual site based on earlier evaluations and discussions with WDOH.

A report (Rhoads and Barnett 2009) that was published before this DQO task documents the assumptions and inputs used to prepare dose-per-unit-release factors for the PNNL Site. The Rhoads and Barnett report (2009) was then used to prepare the Notice of Construction (NOC) applications for the PSF emission units on the PNNL Site. The NOC applications were prepared in a time frame that overlapped

the initial development of this DQO report. Both Rhoads and Barnett (2009) and NOC information were used in the preparation of this report. 


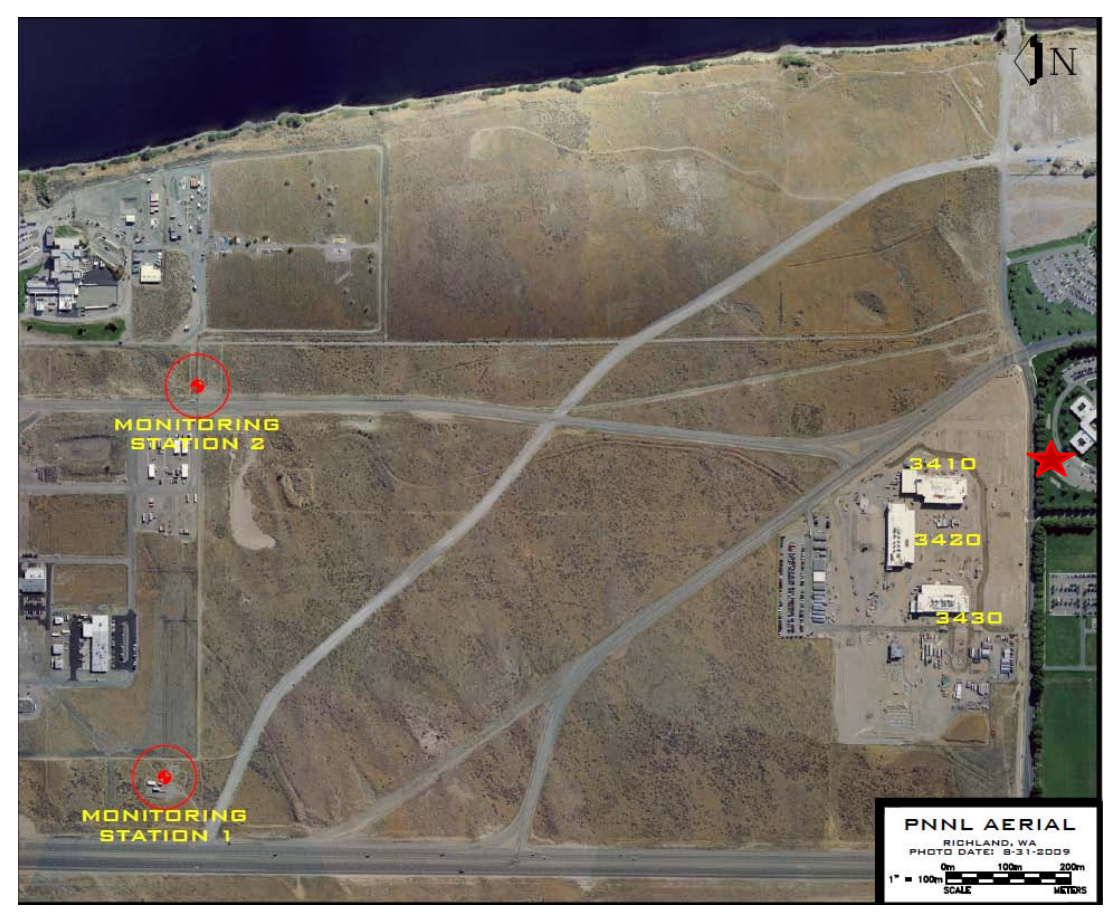

Figure 2.1. Existing Monitoring Stations North of the PNNL Site and MEI ( $\star$ ) Site of WDOH Agreement

\subsection{Applicable Regulatory Requirements}

Regulatory requirements for determining compliance with the radionuclide air emission standards are specified by EPA in 40 CFR Part 61, Subpart H. Similar requirements are identified by the State of Washington in WAC 173-480 and WAC 246-247. The following excerpts from Sections 61.92, 61.93, and 61.94 were deemed most pertinent to this DQO task:

Emissions of radionuclides to the ambient air from Department of Energy facilities shall not exceed those amounts that would cause any member of the public to receive in any year an effective dose equivalent of $10 \mathrm{mrem} / \mathrm{yr}$.

Compliance with this standard shall be determined by calculating the highest effective dose equivalent to any member of the public at any offsite point where there is a residence, school, business or office.

...radionuclide emissions shall be determined and effective dose equivalent values to members of the public calculated using EPA-approved sampling procedures, computer models Clean Air Act Assessment Package-1988 (CAP-88) or AIRDOS-PC, or other procedures for which EPA has granted prior approval. DOE facilities for which the maximally exposed individual lives within 3 kilometers of all sources of emissions in the facility, may use EPA's COMPLY model and associated procedures for determining dose for purposes of compliance. 
Environmental measurements of radionuclide air concentrations at critical receptor locations may be used as an alternative to air dispersion calculations in demonstrating compliance with the standard if the owner or operator meets the following criteria:

- The air at the point of measurement shall be continuously sampled for collection of radionuclides.

- Those radionuclides released from the facility that are the major contributors to the effective dose equivalent must be collected and measured as part of the environmental measurement program.

- Radionuclide concentrations that would cause an effective dose equivalent of $10 \%$ of the standard shall be readily detectable and distinguishable from background.

State agencies may also establish requirements and restrictions in addition to those specified in the federal regulation. For example, the state regulation provides that WDOH “...may require the operation of any emission unit to conduct stack sampling, ambient air monitoring, or other testing...”

(WAC 246-247-075 (9)), in addition to the requirements for stack sampling mandated by the federal regulation. The PNNL Site is proposing the environmental air sampling program in response to a WDOH requirement to confirm low emissions from the PSF; however, the environmental monitoring program would not be the primary method of demonstrating compliance with the regulatory standards for those facilities. Because of the expected low levels of radionuclide emissions from the facilities, stack sampling and dose modeling using EPA-approved software would be used for that purpose.

Methods to demonstrate compliance with the dose standards were developed for effluents routinely emitted from facilities that may release radionuclides to the atmosphere. Neither the environmental monitoring program nor the methods approved by regulations for estimating atmospheric dispersion and dose consequences were intended to be applied to high-level or acute (short-term) emissions from accidents involving radioactive materials. Therefore, the discussions and conclusions in this document are applicable to routine emissions from facilities that may be characterized as chronic emissions (or occurring at substantially the same rate over time).

\subsection{Problem Statement and Preliminary Data}

The objective of this DQO report is to determine the environmental monitoring needs for routine radiological air emissions to the atmosphere from the PNNL Site in north Richland, Washington, in response to $\mathrm{WDOH}$ requirements.

The expected list of isotopes that could be emitted from the PNNL Site can be obtained from the NOC submitted to WDOH. Meteorological data and background concentrations of some radionuclides for the PNNL Site and surrounding area can be obtained from the Hanford Site Meteorological and Climatological Services Project and the Surface Environmental Surveillance Project (SESP). These organizations have collected data on and around the Hanford Site for several decades. Relevant metrological data (e.g., Hoitink et al. 2005) and atmospheric monitoring data (e.g., Poston et al. 2009) can be found in annual Hanford Site reports. 


\subsection{Participants}

The DQO planning team includes:

- Radioactive air task lead with background in regulatory compliance, environmental monitoring, and low-level radiation detection. This member is a final decision maker.

- Environmental engineer with 10 years of experience in sampling and modeling of atmospheric contaminants. In addition, this member is in charge of the Hanford Site atmospheric monitoring task of the SESP.

- Environmental scientist and manager of the Hanford Site’s SESP.

- Two environmental modeling subject matter experts with the ability to perform atmospheric dispersion and MEI dose calculations appropriate to the PNNL Site by using EPA- and WDOHapproved methods and software.

- Quality assurance (QA) engineer with a background in the DQO process and being a chemist in sampling and analysis experience in the Resource Conservation and Recovery Act (RCRA) program. This member is the DQO facilitator.

\subsection{DQO Process and Schedule}

The following documents were consulted for the DQO process used in this document:

- Guidance on Systematic Planning Using the Data Quality Objectives Process, EPA QA/G4, 2/2006,

- Systematic Planning: A Case Study of Particulate Matter Ambient Air Monitoring, EPA QA/CS-2, 3/2007,

- 100-NR-2 Groundwater Operable Unit Ecological Risk Assessment Data Quality Objectives Summary Report, Fluor Hanford, WMP-23141, Rev 0, 6/2005, and

- Regulatory Data Quality Objectives Supporting Tank Waste Remediation System Privatization Project, PNNL, PNNL-12040, Rev 0, 12/1998.

The DQO process was facilitated by the QA engineer. Team members are experienced in using and evaluating output from environmental models. If there was need for other specialists, the team incorporated additional resources into the process.

Team formation began in January 2010. The team started in February 2010 and completed an internal draft on April 28, 2010. A final draft was completed and submitted for review and approval on May 5, 2010.

The document is to be submitted to PNSO and subsequently to WDOH in early June of 2010. 


\subsection{Goal of the DQO}

Chapter 3.0 of the DQO report establishes the principal study question, breaks the study question down into individual questions, and provides a list of actions that might be taken in answering the questions. Which action is selected and what decision is made based on the action will be discussed in the next chapters.

The purpose of this DQO report is to identify the monitoring needs for routine radiological air emissions from the PNNL Site in north Richland, Washington, in response to WDOH requirements.

The information required to make this decision will include the data and bounding conditions to identify, as necessary, monitoring locations and equipment to demonstrate adequate assessment of PNNL Site radiological air emissions at offsite locations. The following supportive questions must be answered to meet the goals of this DQO report.

\subsection{Question \#1}

What radionuclides-of-concern are expected in the air effluent stream on the PNNL Site?

a. State the basis for determining the radionuclides expected to be found.

b. List the method used to determine the radionuclides-of-concern.

c. List the primary radionuclides-of-concern and their form (e.g., particulate, vapor, gas).

Action \#1: Use the available isotope information from permitting applications (the NOCs) to establish a list of radionuclides-of-concern and their particular form.

\subsection{Question \#2}

Where are the potential emission units for radiological air emissions on the PNNL Site and which are most critical for addressing the study question?

a. Identify major emission units and their release characteristics needed for air dispersion modeling (i.e., location, discharge point height and diameter, exit velocity, and temperature).

b. Identify minor emission units, including diffuse/fugitive sites.

Action \#2: Determine which PNNL Site emission unit(s) generates the greatest offsite impacts, based on qualitative or, if needed, quantitative criteria. 


\subsection{Question \#3}

\section{What radionuclide release rates are routinely expected from the PNNL Site emission unit(s) of interest?}

a. Determine the emission rates of the radionuclides-of-concern from routine operations.

b. Under currently conceived operating conditions, determine if any releases are anticipated under routine operations that would be inadequately modeled as a chronic release.

Action \#3: Given PNNL Site emission rates, determine if releases of the radionuclides-of-concern can be adequately and conservatively modeled by air dispersion codes, assuming a uniform emissions rate under routine operations.

\subsection{Question \#4}

Where do models predict the offsite location(s) of maximum impact from PNNL Site emission unit(s) of interest (see Question \#2)?

a. Locations of estimated maximum air concentrations are directly proportional to locations of maximum dose impacts when no previous build-up of atmospheric depositions has occurred.

b. Use the appropriate atmospheric dispersion model to conservatively estimate the locations of the maximum nuclide concentrations from the PNNL Site within the surrounding area, using historical meteorological data and not taking credit for any engineering devices (such as filtration).

c. Establish the criteria for determining the location of the MEI based on the results of 3.4.b.

d. Determine the locations that meet the criteria of 3.4.c and select at least one ideal MEI location for installing an air monitoring station.

Action \#4: Determine the most desirable locations of air monitoring stations in the offsite region surrounding the PNNL Site, based on atmospheric dispersion modeling and MEI criteria. Determine if any existing air monitoring stations are at any of these locations.

\subsection{Question \#5}

What environmental media should be monitored for the effects of radioactive air emissions?

a. Consider all potential media (air, soil, water, food, etc.).

b. Consider both gaseous and particulate contamination for the air pathway.

Action \#5: Determine which environmental media should be collected as part of the proposed sampling program. 


\subsection{Question \#6}

\section{What are the requirements for an adequate radioactive air monitoring program?}

a. The requirements for an air monitoring program for radionuclides are documented in DOE/EH-0173T (DOE 1991) (Environmental Regulatory Guide for Radiological Effluent Monitoring and Environmental Surveillance).

b. Implementation of this guidance at the Hanford Site is contained in DOE/RL-91-50, Revision 4 (Environmental Monitoring Plan for the Hanford Site).

c. The requirements for an adequate radioactive air effluent monitoring program are described in 40 CFR Part 61, Subpart H; § 61.93 (5) as referenced in WAC 246-247. This guidance establishes the analytical and QA requirements that are applied to air monitoring networks.

d. From a sampling perspective, the sampling system and sample collection schedule must collect enough material to be able to measure the radiological releases at levels required to demonstrate compliance with the Table 2 notification levels (40 CFR Part 61, Appendix E). Sampling equipment configurations presently used on the Hanford Site will be used for guidance to identify required flow rates, filter media, and potential compositing designs (Hanf et al. 2007; see Chapter 8).

e. Collectively, these documents comprise the guidance that the WDOH has implemented in administering its regulatory oversight of radioactive air emissions in Washington State at DOE facilities.

Action \#6: Develop an air monitoring program for the PNNL Site, considering applicable regulatory requirements and equipment/sampling specifications, and submit for approval by WDOH.

\subsection{Question \#7}

Are there non-PNNL monitoring programs on or near the site that could be useful in design/implementation of the PNNL Site monitoring plan?

a. Are there any monitoring locations at or near the MEI location?

b. What radionuclides are monitored by other programs?

c. Are there any monitoring locations not at or near the MEI location that could provide concentration data useful to the PNNL Site monitoring plan?

d. Are any data from other programs of sufficient quality to be used in conjunction with, or in lieu of, data collected by PNNL? 
e. Are there procedures, equipment, infrastructure, analytical services contracts, or other useful aspects of other environmental monitoring programs that can be used for the PNNL Site?

Action \#7: Identify what aspects, if any, of other monitoring programs would be usable by the PNNL Site monitoring program; consider results, procedures, locations and equipment. 


\subsection{Inputs}

Chapter 4 of this DQO report lists and describes the sources used for answering the Questions in Chapter 3. Here the type of information is described that is needed to meet performance and acceptance criteria and provides directions for sampling and analysis methods.

Additionally, DOE/EH-0173T, Environmental Regulatory Guide for Radiological Effluent Monitoring and Environmental Surveillance, was published in 1991 and provides guidance for meeting the requirements of DOE Order 5400.5. It includes guidance for airborne effluent monitoring and environmental surveillance. Although its structured content is not explicitly followed in this DQO report, team members referred to its content through the DQO process to make certain that critical items were not omitted or overlooked. It should be additionally noted that DOE Order 5400.5 (for which DOE/EH-0173T [DOE 1991] provides guidance) is currently under revision as Draft DOE Order 458.1.

The PSF underwent slight building modifications during the first quarter of calendar year 2010, which had the effect of changing the effective stack heights for emission modeling. The data presented in this document are current as of April 1, 2010.

\subsection{Emission Units}

The PNNL Site has two facilities with potential emission units: PSF and EMSL. The PSF will have three major emission units with stack identification numbers: EP-3410-01-S, EP-3420-01-S, and EP-3430-01-S. There will also be a number of PSF minor emission units consisting of both stack emissions and fugitive emissions. The minor stack identification numbers are EP-3420-02-S and EP-3430-02-S. There is one fugitive emission location (PSF 3425 Building). There are two possible future minor emission locations (PSF 3410 Building and PSF 3440 Building). EMSL has been exempted from permitting and is allowed to conduct work with volumetrically released materials and limited nondispersible materials released from radiological controls. The criteria for major and minor emission units are as follows:

- Each major emission unit has the potential to contribute $\geq 0.1 \mathrm{mrem} / \mathrm{yr}$ PTE to the MEI.

- Each minor emission unit has the potential to contribute $<0.1$ mrem/yr PTE to the MEI.

An emission unit is defined as any single location that emits or has the potential to emit airborne radioactive material. This may be a point source, nonpoint source, or source of fugitive emissions.

- A point source is a discrete, well-defined location such as a stack or vent.

- A nonpoint source (also called a diffuse source) is a location at which radioactive air emissions originate from an area that may or may not be well-defined such as a contaminated ground area or a near-surface disposal site.

- Fugitive emissions are those that do not and could not reasonably have pass through a point source and are not feasible to directly measure and quantify.

The NOC applications indicate the potential dose to the MEI, which is used to categorize stacks as major or minor emission units. The list of radionuclides-of-concern, those nuclides most greatly 
impacting the categorization as major or minor emission units, are discussed in Section 4.2. Radionuclide release rates for the radionuclides-of-concern are discussed in Section 4.3. The emission unit operating characteristics are discussed in Section 4.4.

\subsection{List of Radionuclides-of-Concern}

An NOC application needs to contain the following information (WAC 2005):

1. The indicated annual possession quantity for each radionuclide.

2. The physical form of each radionuclide (solid, particulate solid, liquid, or gas).

3. Release rates (potential-to-emit) including both abated emissions (potential releases with effluent controls in place) and unabated emissions (assuming no effluent controls, but that facility operations are otherwise normal).

In submitting an NOC application, radionuclides with the potential-to-emit meeting one of the following release criteria are required to be identified by the applicant (WAC 2005):

1. Radionuclides that could contribute $>10 \%$ of the potential-to-emit (PTE) total effective dose equivalent (TEDE) to the MEI.

2. Radionuclides that could contribute $>0.1 \mathrm{mrem} / \mathrm{yr}$ PTE TEDE to the MEI.

3. Radionuclides that could contribute $>25 \%$ of the PTE TEDE to the MEI with effluent controls in place.

Potential releases from the PNNL Site to which the MEI might be exposed consist of airborne effluents from laboratory facilities. For a radionuclide meeting one of the above conditions, the applicant is required to describe the method for monitoring or calculating those radionuclide emissions in sufficient detail to demonstrate compliance with the applicable state requirements.

In determining the PTE, PNNL used the EPA-approved Clean Air Act Assessment Package 1988-Personal Computer (CAP88-PC) Version 3 (Rosnick 2007) software package to develop dose-per-unit-release factors for radionuclide air emissions (CRL-TECH-ESH-007) (Rhoads and Barnett 2009). The dose is estimated using the release rates, in curies per year, for radionuclides expected to be present in the facility multiplied by the corresponding dose-per-unit-release factor. The doses for all radionuclides potentially released are combined to estimate the total annual PTE TEDE to the MEI. Results are used to determine if any of the above PTE criteria are met when submitting an NOC application.

Inputs to developing the list of radionuclides-of-concern are obtained from NOC applications submitted in September 2009 for major emission units. ${ }^{\text {(a) }}$ There were no radionuclides identified that could contribute $>25 \%$ of the PTE TEDE to the MEI with effluent controls in place, and none are shown in the tables below identifying nuclides of interest. Additional minor emission unit NOC applications will also be submitted for the PNNL Site. However, these minor emission units will be limited to

(a) U.S. Department of Energy. 2009. Transmittal of the Pacific Northwest National Laboratory Site Radioactive Air Emissions Notice of Construction Applications for the Operation of the Physical Sciences Facility. Letter from M. J. Weis, PNSO, to P. J. Martell, WDOH dated September 14, 2009, letter number 09-PNSO-0590. 
< 5.0 E-04 mrem/yr PTE to the MEI; therefore, because the potential emissions are orders of magnitude below those identified in the applications for major emission units, only the radioisotopes from the major emission units are considered herein (40 CFR 61, ANSI 1999, PNNL 2007).

Table 4.1 through Table 4.3 indicate the radionuclides-of-concern for each major emission unit on the PNNL Site.

Table 4.1. Radionuclides of Interest: 3410 Building-Materials Science and Technology Laboratory

\begin{tabular}{cccc}
\hline Radioisotope & $\begin{array}{c}>25 \% \text { PTE TEDE to } \\
\text { the MEI with controls } \\
\text { in place }\end{array}$ & $\begin{array}{c}>10 \% \text { PTE TEDE to } \\
\text { the MEI without } \\
\text { controls in place }\end{array}$ & $\begin{array}{c}>0.1 \text { mrem/y PTE TEDE } \\
\text { to the MEI }\end{array}$ \\
\hline${ }^{241} \mathrm{Am}$ & - & - & $\mathrm{X}$ \\
${ }^{243} \mathrm{Am}$ & - & - & $\mathrm{X}$ \\
${ }^{244} \mathrm{Cm}$ & - & - & $\mathrm{X}$ \\
${ }^{60} \mathrm{Co}$ & - & $\mathrm{X}$ & $\mathrm{X}$ \\
${ }^{238} \mathrm{Pu}$ & - & $\mathrm{X}$ & $\mathrm{X}$ \\
${ }^{239} \mathrm{Pu}$ & - & & \\
${ }_{\text {“_“ }=\text { Not Applicable }}$ & & & \\
\hline
\end{tabular}

Table 4.2. Radionuclides of Interest: 3420 Building—Radiation Detection Laboratory

\begin{tabular}{cccc}
\hline & $\begin{array}{c}>25 \% \text { PTE TEDE to } \\
\text { the MEI with controls } \\
\text { in place }\end{array}$ & $\begin{array}{c}>10 \% \text { PTE TEDE to } \\
\text { the MEI without } \\
\text { controls in place }\end{array}$ & $\begin{array}{c}>0.1 \text { mrem/y PTE TEDE } \\
\text { to the MEI }\end{array}$ \\
\hline Radioisotope & - & - & $\mathrm{X}$ \\
${ }^{241} \mathrm{Am}$ & - & - & $\mathrm{X}$ \\
${ }^{243} \mathrm{Am}$ & - & - & $\mathrm{X}$ \\
${ }^{244} \mathrm{Cm}$ & - & $\mathrm{X}$ & $\mathrm{X}$ \\
${ }^{60} \mathrm{Co}$ & - & $\mathrm{X}$ & $\mathrm{X}$ \\
${ }^{238} \mathrm{Pu}$ & - & & ${ }^{239} \mathrm{Pu}$
\end{tabular}

Table 4.3. Radionuclides of Interest: 3430 Building-Ultra-Trace Laboratory

\begin{tabular}{cccc}
\hline Radioisotope & $\begin{array}{c}>25 \% \text { PTE TEDE to } \\
\text { the MEI with controls } \\
\text { in place }\end{array}$ & $\begin{array}{c}>10 \% \text { PTE TEDE to } \\
\text { the MEI without } \\
\text { controls in place }\end{array}$ & $\begin{array}{c}>0.1 \text { mrem/ y PTE TEDE } \\
\text { to the MEI }\end{array}$ \\
\hline${ }^{241} \mathrm{Am}$ & - & - & $\mathrm{X}$ \\
${ }^{243} \mathrm{Am}$ & - & - & $\mathrm{X}$ \\
${ }^{244} \mathrm{Cm}$ & - & $\mathrm{X}$ & $\mathrm{X}$ \\
${ }^{60} \mathrm{Co}$ & - & - & $\mathrm{X}$ \\
${ }^{238} \mathrm{Pu}$ & - & $\mathrm{X}$ & $\mathrm{X}$ \\
${ }^{239} \mathrm{Pu}$ & - & $\mathrm{X}$ & $\mathrm{X}$ \\
${ }^{233} \mathrm{U}$ & - & & \\
\hline
\end{tabular}

\subsection{Radionuclide Release Quantities}

The NOC applications for the PSF 3410, 3420, and 3430 facilities provide information regarding expected releases of the radionuclides-of-concern from the major emission units. The PSF 3425 facility NOC application was also reviewed for consideration of diffuse releases. The facility inventories are 
based on annual possession quantities. The unabated releases of radionuclides from the major stacks are indicated in Table 4.4. The NOC application conservatively estimates abatement by effluent control devices to reduce the releases to $1 \%$ of the indicated unabated release. The tabulated ${ }^{233} \mathrm{U}$ inventory is conservative, considering that it is only pertinent to the 3430 Facility. The 3420- and 3410-facility inventories for this nuclide $(0.0098 \mathrm{Ci})$ are less than $1 \%$ of that indicated for the 3430 Facility.

For diffuse/fugitive releases, by far the greatest impact results are from the estimated inventory and releases of ${ }^{129}$ I and ${ }^{125}$ I from the 3425 Building. However, the NOC application indicates that dose impacts of unabated releases of either of these nuclides are substantially lower than the abated releases of the least impacting radionuclides-of-concern from the major release units (see Table 4.5). Therefore, minor emission units will not be further considered.

Table 4.4. Unabated Release Estimates for Major Emission Units

\begin{tabular}{ccccc}
\hline Radioisotope & Emission Type & $\begin{array}{c}\text { Annual Possession } \\
\text { Inventory }(\mathrm{Ci} / \mathrm{y})^{(\mathrm{a})}\end{array}$ & $\begin{array}{c}\text { Release } \\
\text { Fraction }^{(\mathrm{b})}\end{array}$ & $\begin{array}{c}\text { Unabated Release } \\
\text { Estimate (Ci/y) }\end{array}$ \\
\hline${ }^{241} \mathrm{Am}$ & Alpha & 0.5 & $1 \mathrm{E}-03$ & $5.0 \mathrm{E}-04$ \\
${ }^{243} \mathrm{Am}$ & Alpha & 0.5 & $1 \mathrm{E}-03$ & $5.0 \mathrm{E}-04$ \\
${ }^{244} \mathrm{Cm}$ & Alpha & 1.2 & $1 \mathrm{E}-03$ & $1.2 \mathrm{E}-03$ \\
${ }^{60} \mathrm{Co}$ & Gamma & 30 & $1 \mathrm{E}-03$ & $3.0 \mathrm{E}-02$ \\
${ }^{238} \mathrm{Pu}$ & Alpha & 1.4 & $1 \mathrm{E}-03$ & $1.4 \mathrm{E}-03$ \\
${ }^{239} \mathrm{Pu}$ & Alpha & 1.2 & $1 \mathrm{E}-03$ & $1.2 \mathrm{E}-03$ \\
${ }^{233} \mathrm{U}$ & Alpha & 9 & $1 \mathrm{E}-03$ & $9.0 \mathrm{E}-03$ \\
\hline
\end{tabular}

(a) Maximum possession limit for any PSF facility per NOC applications. ${ }^{(a)}$

(b) Release form is particulate/liquid as identified in 40 CFR 61, Appendix D.

Table 4.5. Major and Minor Emission Unit Release Impact Comparison

\begin{tabular}{ccccc}
\hline Facility & Radioisotope & $\begin{array}{c}\text { Release Estimate } \\
(\mathrm{Ci} / \mathrm{y})\end{array}$ & $\begin{array}{c}\text { Release Estimate: } \\
\text { Abated or Unabated }\end{array}$ & $\begin{array}{c}\text { Impact Estimate of } \\
\text { Release (mrem/y) }\end{array}$ \\
\hline 3410 & ${ }^{243} \mathrm{Am}$ & $5 \mathrm{E}-06$ & abated & $3.2 \mathrm{E}-03$ \\
3410 & ${ }^{60} \mathrm{Co}$ & $3 \mathrm{E}-04$ & abated & $1.6 \mathrm{E}-03$ \\
3425 & ${ }^{125} \mathrm{I}$ & $1 \mathrm{E}-06$ & unabated & $2.3 \mathrm{E}-05$ \\
3425 & ${ }^{125} \mathrm{I}$ & $5 \mathrm{E}-07$ & unabated & $2.4 \mathrm{E}-04$ \\
\hline
\end{tabular}

\subsection{Major Emission Unit Characteristics}

The stacks discussed in the following sections meet the criteria for major emission units described in the previous section. The characteristics of these units relevant to environmental modeling are tabulated (Table 4.6). The characteristics indicated are those based on anticipated operations (current April 1, 2010).

(a) U.S. Department of Energy. 2009. Transmittal of the Pacific Northwest National Laboratory Site Radioactive Air Emissions Notice of Construction Applications for the Operation of the Physical Sciences Facility. Letter from M. J. Weis, PNSO, to P. J. Martell, WDOH dated September 14, 2009, letter number 09-PNSO-0590. 
Table 4.6. Major Emission Unit Operation Parameters

\begin{tabular}{lccc}
\hline & Materials Science and & Radiation Detection & \\
\multicolumn{1}{r}{ Building Name: } & Technology Laboratory & Laboratory & Ultra-Trace Laboratory \\
\hline \multicolumn{1}{r}{ Stack ID: } & EP-3410-01-S & EP-3420-01-S & EP-3430-01-S \\
\hline Stack Height & $13.72 \mathrm{~m}(45 \mathrm{ft})$ & $15.51 \mathrm{~m}(50.9 \mathrm{ft})$ & $13.53 \mathrm{~m}(44.4 \mathrm{ft})$ \\
Stack Discharge Diameter & $0.81 \mathrm{~m}(32 \mathrm{in})$ & $1.32 \mathrm{~m}(52 \mathrm{in})$ & $1.12 \mathrm{~m}(44 \mathrm{in})$ \\
Average Exit Velocity & $12.47 \mathrm{~m} / \mathrm{s}(40.9 \mathrm{ft} / \mathrm{s})$ & $18.47 \mathrm{~m} / \mathrm{s}(60.6 \mathrm{ft} / \mathrm{s})$ & $18.57 \mathrm{~m} / \mathrm{s}(60.9 \mathrm{ft} / \mathrm{s})$ \\
Average Exit Flow Rate & $6.47 \mathrm{~m}^{3} / \mathrm{s}(13700 \mathrm{cfm})$ & $25.31 \mathrm{~m}^{3} / \mathrm{s}(53625 \mathrm{cfm})$ & $18.22 \mathrm{~m}^{3} / \mathrm{s}(38600 \mathrm{cfm})$ \\
Average Stack Temperature & $22^{\circ} \mathrm{C}\left(72^{\circ} \mathrm{F}\right)$ & $22^{\circ} \mathrm{C}\left(72^{\circ} \mathrm{F}\right)$ & $22^{\circ} \mathrm{C}\left(72^{\circ} \mathrm{F}\right)$ \\
Effective Stack Height & $28.8 \mathrm{~m}(94.5 \mathrm{ft})$ & $44.2 \mathrm{~m}(145.1 \mathrm{ft})$ & $37.3 \mathrm{~m}(122.5 \mathrm{ft})$ \\
\hline
\end{tabular}

\subsection{Meteorological Data}

The meteorological conditions for the PNNL Site and surrounding area can be obtained from the Hanford Meteorological and Climatological Services Project that has been in operation since 1944 (Hoitink et al. 2005). Meteorological measurements are taken to support Hanford Site emergency preparedness and response, operations, and atmospheric dispersion calculations for dose assessments. Support is provided through weather forecasting and by maintaining and distributing climatological data. Forecasting is provided to help manage weather-dependent operations. Climatological data are used to help plan weather-dependent activities and as a resource to assess the environmental effects of site operations. The Hanford Meteorology Station relies on data provided by the Hanford Meteorological Monitoring Network. This network consists of 30 remote monitoring stations that transmit data to the Hanford Meteorology Station via radio telemetry every 15 minutes. There are twenty-seven 9-meter (30-foot) towers and three 61-meter (200-foot) towers. Meteorological information collected at these stations includes wind speed, wind direction, temperature, precipitation, atmospheric pressure, and relative humidity; however, not all of these data are collected at all stations.

For this report, CAP88-PC calculations were performed using historic meteorological data for the 300 Area (station 11) averaged from 1983 through 2006 (see Appendix A). Because the 300 Area is located about $1 \mathrm{~km}$ north of the PSF complex, the 300 Area dataset was determined to be the most appropriate meteorological data available to determine atmospheric dispersion of releases in the PSF region. Other potential meteorological stations are located at a greater distance from the source facilities (e.g., the Richland airport, near Horn Rapids, or across the Columbia River to the north of the 300 Area), and are separated from those facilities by topographical features that would likely alter the wind directions. Therefore, the 300 Area meteorological dataset reflects atmospheric conditions most appropriate to select the location for an environmental monitoring station over the long-term.

The frequency that the winds blow in a particular direction can be indicative of the direction of maximum impact. The average frequency which the wind blew toward a particular direction for the 300 Area from 1983 through 2006 is shown in Table 4.7. Any frequency over 6.25\% is greater than an evenly distributed frequency (100\% divided by 16 compass pts). However, the wind speed and stability class, an indicator of air turbulence, also influence atmospheric dispersion, hence the need for modeling estimated downwind concentrations of radionuclides potentially released from the PSF. 
Table 4.7. Average Frequency of Wind Direction for the 300 Area Station (1983 through 2006)

\begin{tabular}{cc}
\hline Direction & \% of Time \\
\hline NW & 10.64 \\
NE & 10.27 \\
SSE & 9.35 \\
NNE & 9.16 \\
S & 8.80 \\
WNW & 7.10 \\
N & 6.84 \\
NNW & 6.56 \\
SE & 6.17 \\
ENE & 5.79 \\
SSW & 4.90 \\
E & 3.33 \\
W & 3.07 \\
ESE & 2.99 \\
SW & 2.72 \\
WSW & 2.17 \\
\hline
\end{tabular}

\subsection{Air Dispersion Modeling, CAP88-PC Model}

The CAP88-PC version3 computer code (Rosnick 2007) is an Environmental Protection Agency approved model that has previously been used to determine 40 CFR 61 Subpart H compliance at the Hanford Site. The software uses a Gaussian plume model to estimate atmospheric transport for chronic releases of radionuclides. It has been used for this evaluation to determine the location of the MEI for radionuclide emissions from the PNNL Site. Input parameters required for the atmospheric dispersion calculations include:

- Distance and direction to potential receptor locations

- Local meteorological data

o Data array of wind frequency by direction, speed, and atmospheric stability

o Annual precipitation rate

o Annual average ambient temperature

o Lid height

o Absolute humidity

- Stack Parameters

o Height

o Diameter

- Plume rise parameters

o Momentum plume - exit velocity

o Buoyant plume - heat release rate 
- Radionuclide Data

o List of radionuclides in effluent stream

o Release rates by radionuclide (required for dose, not required for dispersion estimate)

o Radionuclide chemical/physical form

Entering stack release characteristics and the long-term average meteorological data set into a CAP88 case provides dispersion calculations for 16 compass sectors (e.g., N, NNE, NE) at up to 20 user-specified distances from the release point. The results are calculated as a normalized air concentration (radioactivity per cubic meter per radioactivity released per second, or sec $/ \mathrm{m}^{3}$ ) also referred to as the Chi-over-Q (X/Q) in the indicated sector for each distance. High X/Q values indicate a sector with greater potential dose compared to lower X/Q values. The sectors with greater impact at the potential MEI locations were determined for each of the three major PSF emission units using that information.

\subsection{MEI Exposure Characteristics}

The MEI dose is determined from the radionuclide releases, the environmental dispersion of the release, and the MEI pathways of exposure. The radionuclides and environmental dispersion inputs were discussed in the previous section. The exposure pathways considered for the MEI are inhalation, ingestion, and external exposure. Outside the PNNL Site boundary are office buildings accessible to members of the public, with other businesses, residences, and schools a considerable distance beyond. Therefore, for initial modeling, the MEI is assumed to be an office worker (member of the public) in facilities just beyond the PNNL Site fence line. For an office worker, the inhalation and external pathways are the most likely routes of exposure. The ingestion pathways would apply to individuals who consumed food produced in the immediate vicinity. However, food production is minimal near the PNNL Site, and estimates of radiation dose to these individuals would be conservatively high because of that assumption, as well as the assumption of full-time occupancy at the nearby office facilities.

\subsection{Relevant Maximum Air Concentration Location(s)}

Note: The data presented here results from the output of Sections 4.4 through 4.6. The stack operating characteristics (Section 4.4) and meteorological data (Section 4.5) were used in the CAP88-PC model (Section 4.6) to determine locations of maximum air concentrations for each of the PNNL Site major emission units.

CAP88-PC version 3 was used to model the air concentrations at various radial sectors from the PSF major emission units. The maximum air concentration sector(s) indicates the location where a person would receive the maximum dose from PSF emissions. Tables of the X/Q values from each PSF major emission unit are provided in Appendix B. The 3410 Building emission unit creates the greatest offsite air concentrations at potential MEI locations. As the greatest potential contributor, dispersion data from that unit is presented as an example of dispersion data output.

To present information tabulated in Appendix B (Table B.1), two figures were created using the $\mathrm{X} / \mathrm{Q}$ results from the 3410 Building emission units. 
- Figure 4.1. X/Q Values (s/m3) for Indicated Location for Five Distances from PSF 3410 Building Points on the radar plot indicate the relative air concentration estimates, as represented by the $\mathrm{X} / \mathrm{Q}$ values, at five distances.

- Figure 4.2. Air Concentration Ratios of the Indicated Location to that of a Proposed Station Location (480 m SSE of 3410 Building) when greater than 0.5 or at the Fenceline Location.

Relative air concentration data are indicated:

o ratios of X/Q values to the X/Q value of the $480 \mathrm{~m} \mathrm{SSE}$ average location (“480 m SSE”) to normalize the data,

o only those ratios that are 0.5 or greater (i.e., $\geq 50 \%$ ) for distances from $100 \mathrm{~m}$ to $1000 \mathrm{~m}$ from the 3410 stack are displayed,

o the ratio to the fence line X/Q to the $480 \mathrm{~m} \mathrm{SSE} \mathrm{X/Q} \mathrm{is} \mathrm{displayed,} \mathrm{and}$

$\mathrm{O}$ in addition, a checkmark on the X-axis indicates locations where a member of the public would be expected to frequently occupy the location near (within approximately $100 \mathrm{~m}$ ) of the PNNL Site fence line. All other near fence line locations are either vacant land, highway, or Columbia River sites (see Figure 4.3).

Additional information regarding the selection of the $480 \mathrm{~m}$ SSE $\left(X / Q=1.44 \mathrm{E}-6 \mathrm{~s} / \mathrm{m}^{3}\right)$ is provided in the Decision Section 6.4. A location having $50 \%$ or greater air concentration ratio to a maximum value was, by team consensus, determined to be adequate for environmental monitoring purposes when environmental and meteorological conditions, as well as air monitoring station operations, and air sample analysis uncertainties are considered. In other words, a location with a X/Q value that is $50 \%$ or more than that of a X/Q for a location of interest are considered to be reasonably equivalent when the uncertainties in the determination of air concentrations are considered. 


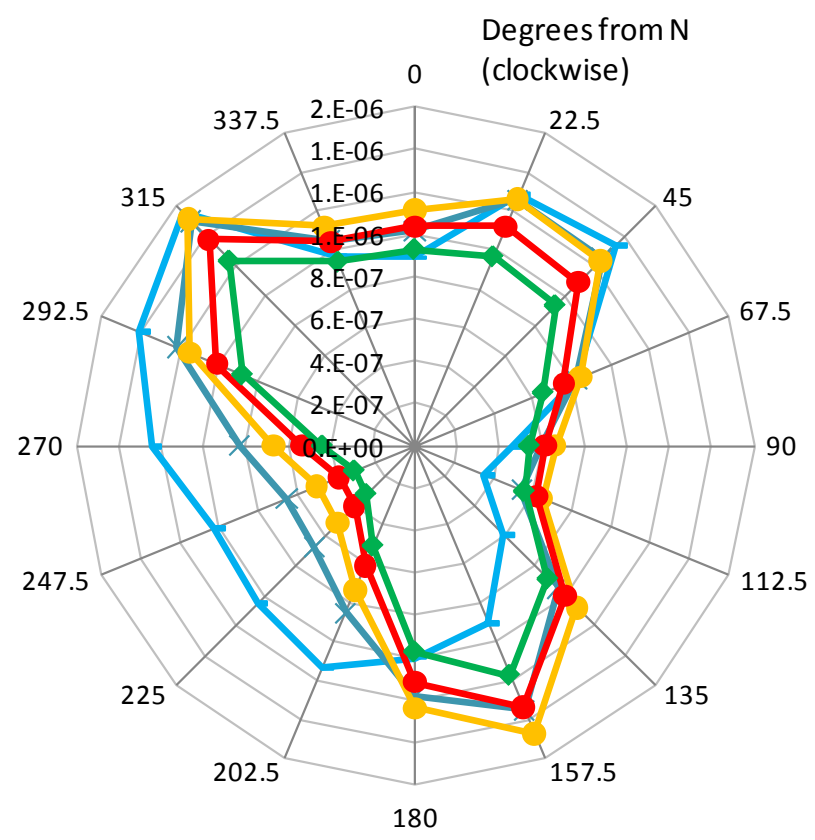

Chi/Q Values $\left(\mathrm{s} / \mathrm{m}^{3}\right)$ at Indicated Distance from 3410 Building Emission Unit

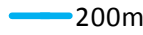

$\div 400 m$

$-600 m$

$-800 m$

$-1000 m$

Figure 4.1. X/Q Values $\left(\mathrm{s} / \mathrm{m}^{3}\right)$ for Indicated Location for Five Distances from PSF 3410 Building

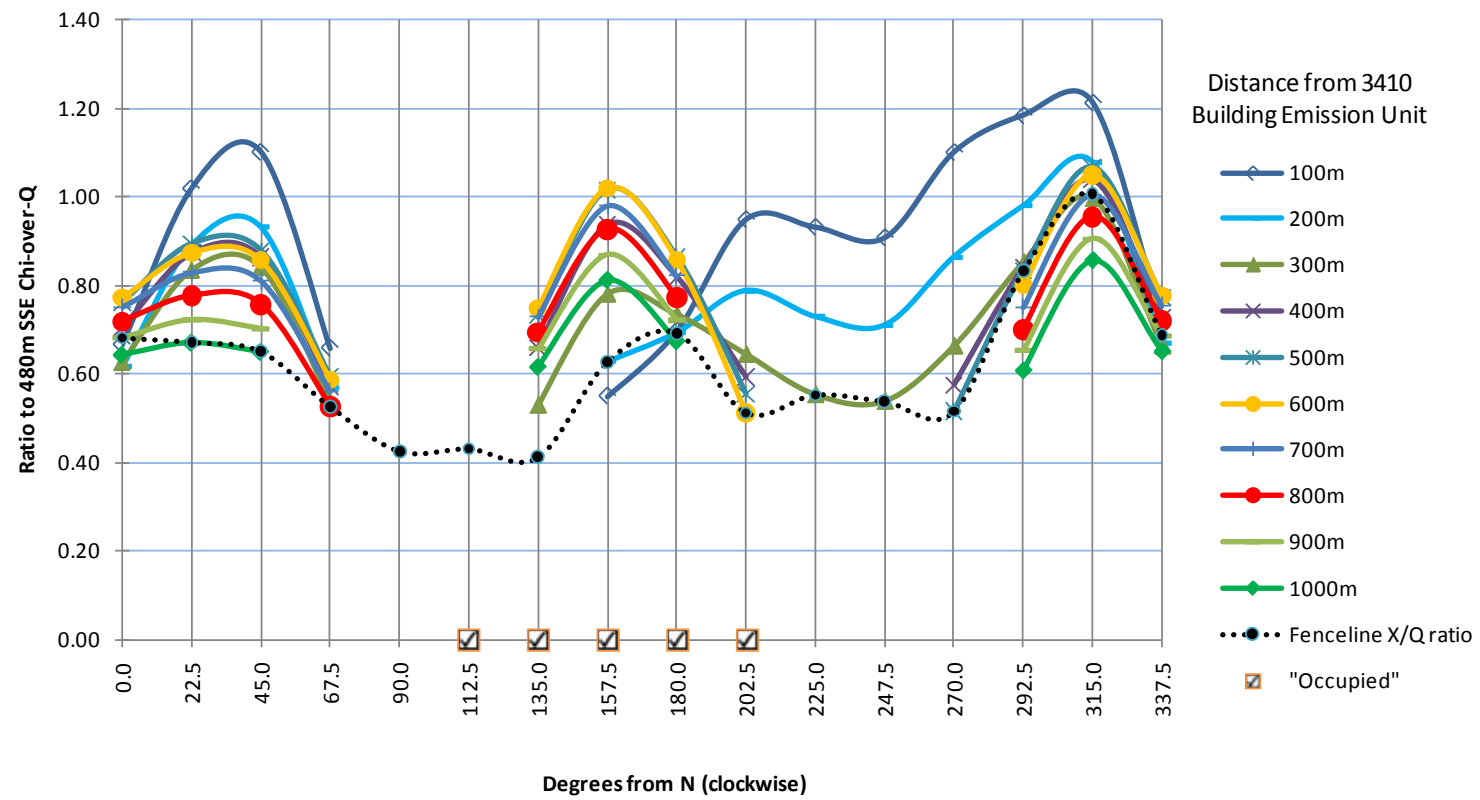

Figure 4.2. Air Concentration Ratios of the Indicated Location to that of a Proposed Station Location (480 m SSE of 3410 Building) when greater than 0.5 or at the Fenceline Location 


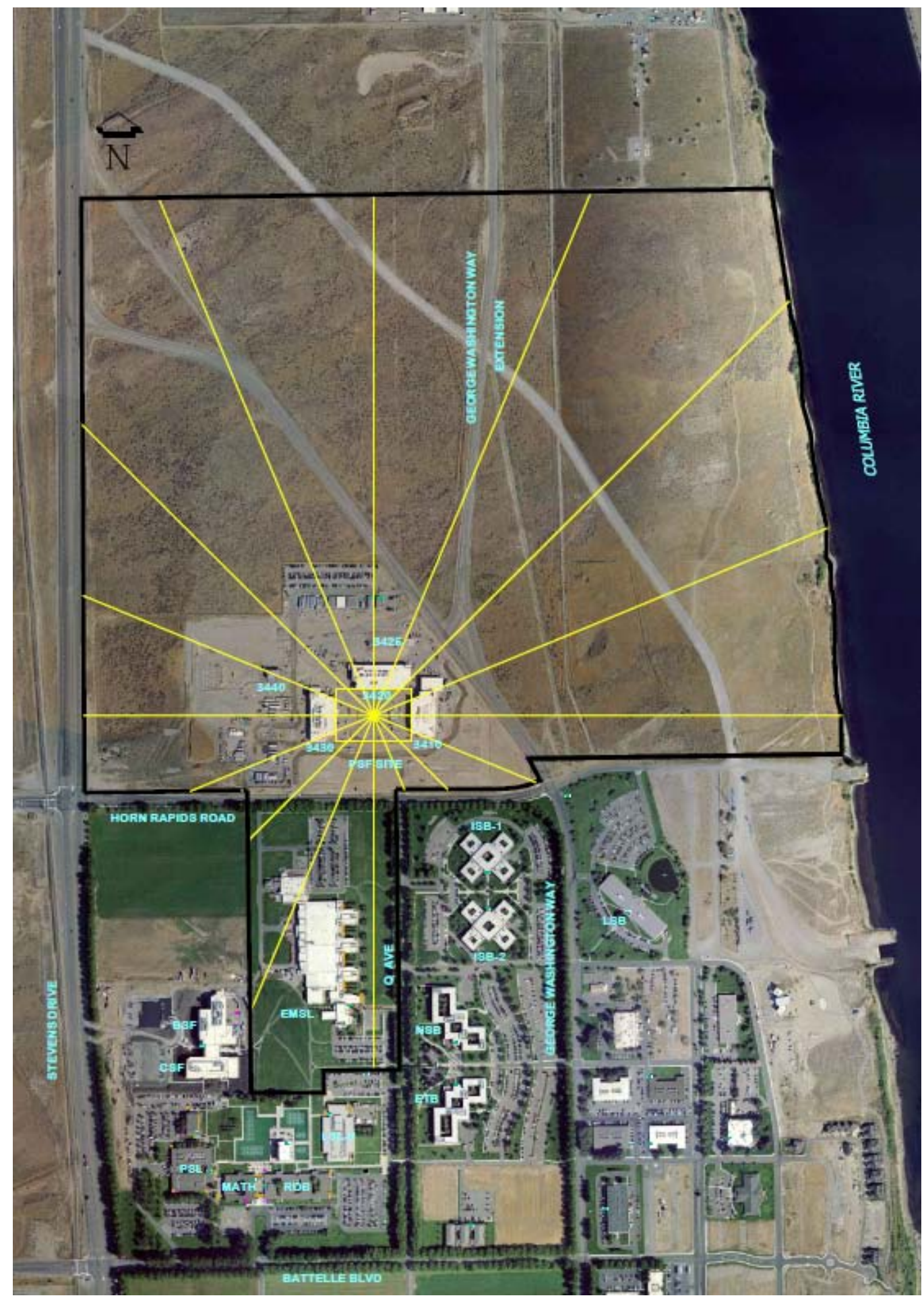

Figure 4.3. Boundary Visual with Yellow Lines Indicating Centerline Compass Directions from PSF 


\subsection{Adequate Monitoring Program}

The approach used in the Environmental Monitoring Plan will meet the guidance of DOE/EH-0173T (DOE 1991) and will generally follow the methods and strategy utilized on both the near field and environmental surveillance programs presently deployed at Hanford. Both of these programs meet policy and guidance requirements established by the WDOH for Hanford Site air emissions.

1. The air at the point of measurement shall be continuously sampled for collection of radionuclides. This is defined as $85 \%$ of the operational sample collection time. Compositing frequency cannot exceed six months.

2. Those radionuclides released from the facility (Table 4.8), which are the major contributors to the effective dose equivalent must be collected and measured as part of the environmental measurement program at a minimum detectable amount that meets the concentrations specified in Table 2 (40 CFR Part 61, Appendix E).

3. Radionuclide concentrations which would cause an effective dose equivalent of $10 \%$ of the standard shall be readily detectable and distinguishable from background.

4. A QA program and analytical methods shall be conducted that are consistent with performance requirements for effluent monitoring (e.g., NQA-1, EPA QA/R-5 for QA, and Method 114 for analytical procedures).

Table 4.8. Radionuclides to Be Monitored at the PNNL Site

\begin{tabular}{|c|c|c|c|}
\hline Radioisotope & $\begin{array}{l}\text { Approximate } \\
\text { Half-life }(y)^{\mathrm{a}}\end{array}$ & $\begin{array}{c}\text { Table } 2^{\mathrm{b}} \\
\text { Concentration } \\
\left(\mathrm{pCi} / \mathrm{m}^{3}\right)\end{array}$ & $\begin{array}{c}\text { Notification } \\
\text { concentration }(10 \% \\
\left.\text { Table } 2^{\mathrm{b}}\right)\end{array}$ \\
\hline${ }^{241} \mathrm{Am}$ & 432 & $1.90 \mathrm{E}-03$ & $1.90 \mathrm{E}-04$ \\
\hline${ }^{243} \mathrm{Am}$ & 7,380 & $1.80 \mathrm{E}-03$ & $1.80 \mathrm{E}-04$ \\
\hline${ }^{244} \mathrm{Cm}$ & 18 & $3.30 \mathrm{E}-03$ & $3.30 \mathrm{E}-04$ \\
\hline${ }^{60} \mathrm{Co}$ & 5 & $1.70 \mathrm{E}-02$ & $1.70 \mathrm{E}-03$ \\
\hline${ }^{238} \mathrm{Pu}$ & 88 & $2.10 \mathrm{E}-03$ & $2.10 \mathrm{E}-04$ \\
\hline${ }^{239} \mathrm{Pu}$ & 24,065 & 2.00E-03 & $2.00 \mathrm{E}-04$ \\
\hline${ }^{233} \mathrm{U}$ & 158,500 & 7.10E-03 & 7.10E-04 \\
\hline
\end{tabular}

(a) ICRP 1983

(b) Table 2 of 40 CFR Part 61, Appendix E

\subsection{Existing Hanford Site Monitoring Station Locations}

The SESP has several monitoring locations that could be useful for PNNL Site monitoring, although none are near the potential MEI location. There are two stations residing approximately 1200 meters north of the PNNL Site emission units. Another monitoring site is located approximately 1400 meters to the south-southwest of the PNNL Site emission units. Of the radioisotopes emitted from the PNNL Site, samples collected for the SESP are currently analyzed for ${ }^{60} \mathrm{Co},{ }^{238} \mathrm{Pu}$, and ${ }^{239} \mathrm{Pu}$ (Poston et al. 2009). The detection limits for samples collected by the SESP are sufficiently low that they would be adequate for the PNNL Site monitoring purposes (Poston et al. 2009). Additionally, the collection and analytical 
methods used by the SESP would be appropriate to implement in the PNNL Site monitoring. The monitoring locations and procedures can be found in project-specific documents (Hanf et al. 2007). ${ }^{\text {(a) }}$

(a) Fritz, BG, JA Stegen, GW Patton and TM Poston. 2009. Surface Environmental Surveillance Project Locations Manual, Vol. 1-“Air and Water.” Pacific Northwest National Laboratory, Richland, Washington. 


\subsection{Boundaries}

Chapter 5 of the DQO report discusses the logistics of implementing the objectives. Here the boundaries are listed as they exist in the geographic limits (spatial) as well as in the practical areas of location, support, etc. To provide a viable solution to the problem, all factors have to be taken into consideration.

\subsection{Modeling Boundaries}

To appropriately locate environmental sampling stations for airborne radionuclides, it is necessary to understand the long-term transport of radioactive effluents from the PNNL Site to potential receptor locations. Atmospheric transport for chronic releases is typically estimated with a Gaussian plume model applied to local meteorological data. The CAP88-PC software implements such a model and was used as the primary means for calculating the relative atmospheric dispersion of radionuclides released from the PNNL facilities. The CAP88-PC model accounts for stack-specific parameters such as stack height, diameter, flow rate, and temperature to adjust the dispersion calculations relative to a ground-level release. A similar model, as implemented in the GENII software (Napier et al. 2008), was used as a benchmark to confirm the results of the CAP88-PC calculations. Calculated X/Q values from the two software packages were similar, although they were not identical because of the different algorithms used in the codes. As noted previously, meteorological data collected at the 300 Area between 1983 and 2006 were selected as the most appropriate data set to determine long-term atmospheric dispersion at the PNNL Site.

The output of atmospheric dispersion calculations from the CAP88-PC software provides tables of $\mathrm{X} / \mathrm{Q}$ values by distance and direction for each radionuclide listed in the facility effluent stream. The relative atmospheric dispersion is adjusted to account for radioactive decay during transit to the receptor location (negligible for medium- to long-lived isotopes) as well as removal of radionuclides from the plume by deposition onto the ground. In this evaluation, representative radionuclides for three classes of radioactive materials were modeled:

- longer lived, non-depositing gases (represented by tritium),

- longer lived depositing particulates (represented by ${ }^{239} \mathrm{Pu}$ ), and

- longer lived reactive particulates with a higher deposition rate (represented by ${ }^{129} \mathrm{I}$ ).

Short-lived radionuclides were not evaluated for this purpose because their estimated downwind concentrations would be lower than those that do not undergo significant radioactive decay during transit. Although tritium was not listed as an isotope of concern, the results for tritium were used as the primary basis for estimating atmospheric dispersion at the potential receptor locations because they are somewhat higher than calculated values for the two classes of particulates. At the receptor distances and directions relevant to this evaluation, the results for all three classes of materials were similar and would yield substantially the same conclusions regarding appropriate locations for environmental sampling. 


\subsection{Spatial Boundaries}

Dispersion modeling for the PNNL Site consisted of calculating X/Q values in 16 compass directions and 20 distances relative to the three major emission units (the 3410, 3420, and 3430 Buildings). The distances evaluated ranged from $100 \mathrm{~m}$, which is the near limit imposed by the software, to $10,000 \mathrm{~m}$, which is beyond the boundary of the PNNL Site for any of these stacks.

The EPA regulations define potential receptor locations for demonstrating compliance with the dose standard as "....an offsite point where there is a residence, school, business or office.” In WAC 246-247, the MEI is defined as "any member of the public (real or hypothetical) who abides or resides in an unrestricted area and may receive the highest TEDE from the emission unit(s) under consideration, taking into account all exposure pathways affected by the radioactive air emissions.” WDOH has historically applied this definition to any member of the public that may spend a substantial fraction of a year at a location where access is not controlled by DOE, including non-DOE enterprises that may lie within the physical boundaries of a DOE facility.

All existing locations that meet these criteria are in a generally southerly direction relative to the PNNL Site. The closest regularly occupied facility outside the PNNL Site boundary is approximately $175 \mathrm{~m}$ toward the SSE. Therefore, in addition to the location of expected maximum X/Q, facilities in this general area were modeled to determine the relative consequences of air emissions from the PNNL Site at each potential receptor location. Table 5.1 lists the specific facilities and their distance and direction from each of the PNNL Site major emission units.

Figure 5.1 indicates the receptor locations relative to PSF.

Table 5.1. Potential Receptor Locations for Radioactive Air Emissions from PNNL Site Major Emission Units

\begin{tabular}{cccc}
\hline & \multicolumn{3}{c}{ Nearest Distance and Direction from PNNL Site Major Emission Units to } \\
& \multicolumn{3}{c}{ Potential Receptor Location } \\
\cline { 2 - 4 } Receptor Location & 3410 Bldg. Stack & 3420 Bldg. Stack & 3430 Bldg. Stack \\
\hline ISB-1 & $170 \mathrm{~m} \mathrm{SSE}$ & $280 \mathrm{~m} \mathrm{SSE}$ & $280 \mathrm{~m} \mathrm{SE}$ \\
ISB-2 & $280 \mathrm{~m} \mathrm{SSE}$ & $380 \mathrm{~m} \mathrm{SSE}$ & $370 \mathrm{~m} \mathrm{SE}$ \\
NSB & $430 \mathrm{~m} \mathrm{~S}$ & $510 \mathrm{~m} \mathrm{~S}$ & $470 \mathrm{~m} \mathrm{SSE}$ \\
LSL-2 & $640 \mathrm{~m} \mathrm{SSW}$ & $710 \mathrm{~m} \mathrm{~S}$ & $570 \mathrm{~m} \mathrm{~S}$ \\
BSF & $530 \mathrm{~m} \mathrm{SW}$ & $570 \mathrm{~m} \mathrm{SW}$ & $450 \mathrm{~m} \mathrm{SW}$ \\
\hline
\end{tabular}




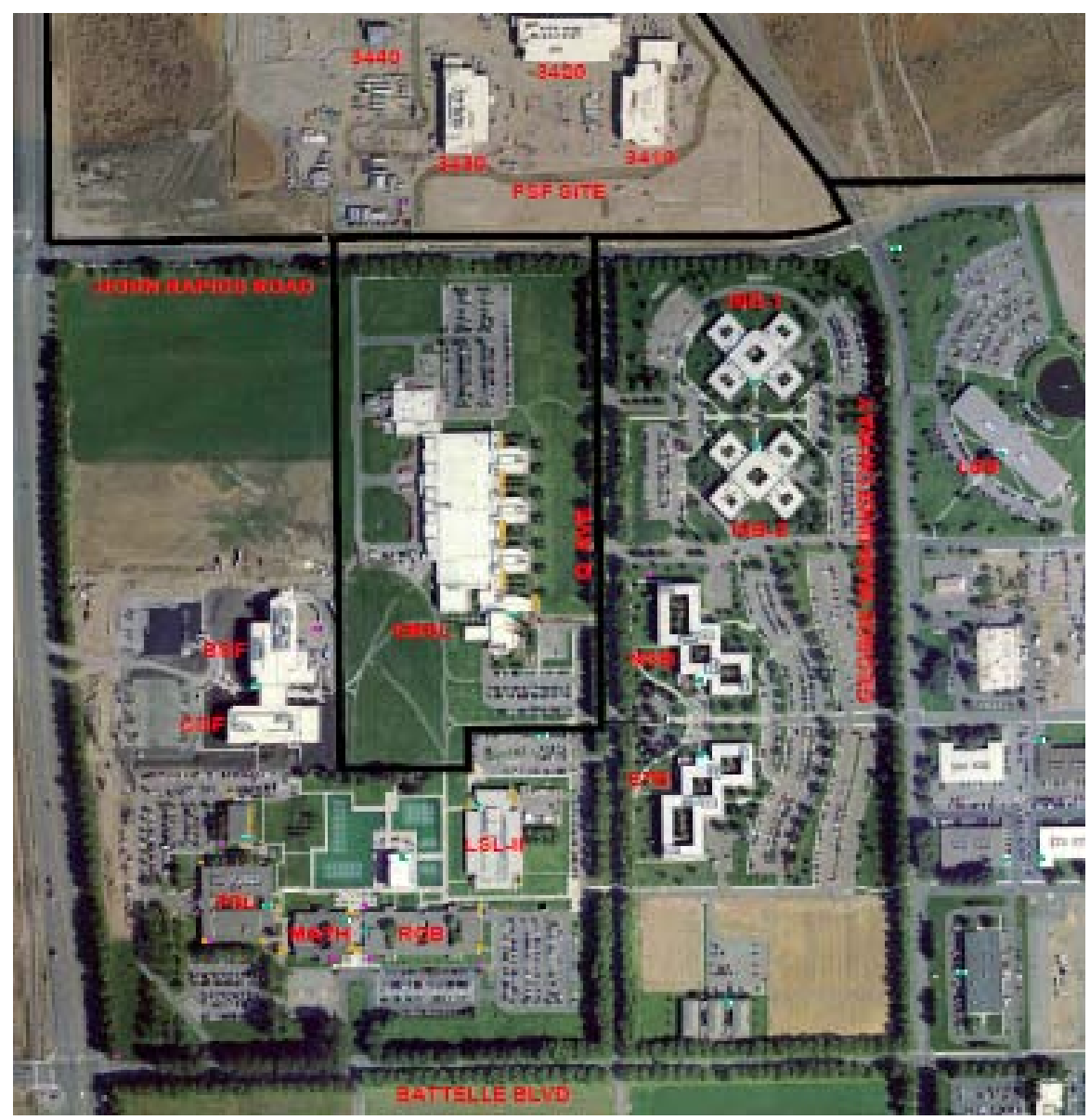

Figure 5.1. Offsite Buildings with Potential Receptors

\subsection{Temporal Boundaries}

Several time periods are relevant to this DQO. Air monitoring regulations require that dose to the member of the public be evaluated for each calendar year. Inputs required for the annual dose calculation, which are also considered over the same 1-year time frame, are emissions of radionuclides (Ci), meteorology (wind speed, wind direction, stability class), and exposure characteristics (e.g., time spent outdoors, garden productivity). The radionuclide emission rates and meteorology change from one calendar year to the next. Exposure characteristics generally do not change.

The temporal boundary for the sampling station is composite measurement of quarterly samples for a calendar year.

Another temporal boundary relevant to this DQO is the presence of additional buildings or major emission units on the PNNL Site. This boundary generally does not change. Changes would occur as a result of construction activities or modifications to NOCs. The impact of a new building on the PNNL Site may either change the dispersion modeling of emission units already addressed in this DQO or may introduce a new emission unit. 


\subsection{Practical Constraints}

To identify the most effective sites for environmental sampling of radioactive air emissions, it is desirable to place the station near a location where the expected radionuclide air concentrations are high enough to be detectable. Other constraints exist as well, including:

- Availability of space to house the station,

- Availability of power,

- Accessibility for sample retrieval,

- Existence of structures or vegetation between the source and sample station that might perturb transport of airborne radionuclides,

- Vulnerability to vandalism or other damage (by water, automobiles, etc), and

- Vulnerability to external factors, such as dust generated by traffic, that could reduce sampler efficiency. 


\subsection{Decision Rules}

Chapter 6 of the DQO report provides the answers to the questions that were asked in Chapter 3. The decisions are based on assumptions and the data inputs listed in Chapter 4.

\subsection{Decision \#1}

Question \#1: What radionuclides-of-concern are expected in the air effluent stream on the PNNL Site?

Action \#1. Use the available isotope information from permitting applications (the NOCs) to establish a list of radionuclides-of-concern and their particular form.

The major emission units are expected to produce unabated impacts to the MEI that are three orders of magnitude greater than the minor emission units and abated impacts about 140 times greater than minor emission units. Therefore, the radionuclides-of-concern for the major emission units are determined to be of greatest interest. Table 6.1 lists the radionuclides that have been identified as major contributors to the potential offsite dose from PNNL Site airborne effluents based on submitted NOC applications (e.g., those that meet the release criteria identified in Section 4.1).

Upon review of the radionuclides potentially emitted from the major and minor emission units, there are no radioactive gases or vapors that contribute substantially to the potential offsite dose from any emission unit that would require monitoring. Therefore, only particulate radionuclides are addressed with respect to the environmental sampling program.

Table 6.1. List of Radionuclides-of-Concern

\begin{tabular}{c}
\hline Radioisotope \\
\hline${ }^{241} \mathrm{Am}$ \\
${ }^{243} \mathrm{Am}$ \\
${ }^{244} \mathrm{Cm}$ \\
${ }^{60} \mathrm{Co}$ \\
${ }^{238} \mathrm{Pu}$ \\
${ }^{239} \mathrm{Pu}$ \\
${ }^{233} \mathrm{U}$ \\
\hline
\end{tabular}

Decision \#1: The radionuclides-of-concern that have been identified from the permitting process are particulate forms of ${ }^{241} \mathrm{Am},{ }^{243} \mathrm{Am},{ }^{244} \mathrm{Cm},{ }^{60} \mathrm{Co},{ }^{238} \mathrm{Pu},{ }^{239} \mathrm{Pu}$, and ${ }^{233} \mathrm{U}$. 


\subsection{Decision \#2}

\section{Question \#2: Where are the potential emission units for radiological air emissions on the PNNL}

Site?

Action \#2. Determine which PNNL Site emission unit(s) generates the greatest offsite impacts, based on qualitative or, if needed, quantitative criteria.

The input data provided in Section 4.3, Radionuclide Release Quantities, also indicates the estimated impact from emissions, as documented in the NOC applications. This information was used as the basis for the Decision \#2.

Decision \#2. Using only major emission units and their emission unit characteristics, model the radionuclide releases based on current EPA-approved air dispersion codes.

\subsection{Decision \#3}

Question \#3: What radionuclide release rates are routinely expected from the PNNL Site emission unit(s) of interest?

Action \#3: Given PNNL Site emission rates, determine if releases of the radionuclides-of-concern can be adequately and conservatively modeled by air dispersion codes using a uniform emission rate under routine operations.

This DQO considers the measurement of routine releases of radioactive materials to the air. The source-release characteristics, whether they are released at a relatively constant rate over time or occur as larger, intermittent releases, can influence the ability to detect the radionuclides. In the case of PSF building releases, the radioactive sources are expected to be low-level and relatively constant over time. Therefore, they may be characterized as chronic releases and are adequately modeled by the EPA-approved software. If acute releases were anticipated from non-sampled stacks, alternative methods for modeling atmospheric transport may be warranted for the radionuclides involved.

Decision \#3: A chronic release rate of radionuclides-of-concern can be used for modeling release and exposure (i.e., dose). Normal facility operations as currently planned are not expected to result in significant acute releases of radioactive materials. If either planned or unanticipated short-term releases occur at the facilities, the need for alternative assessment methods would be evaluated.

\subsection{Decision \#4}

Question \#4: Where do models predict the offsite location(s) of maximum impact from PNNL Site emission unit(s) of interest?

Action \#4. Determine the most desirable locations of air monitoring stations in the offsite PNNL Site region, based on atmospheric dispersion modeling, and MEI criteria. Determine if any existing air monitoring stations are at any of these locations. 
An air monitoring station would ideally be located at a point where it can most successfully capture emissions; in other words, the location where the highest air concentrations from an emission source would be found. CAP88-PC modeling, through X/Q table output (see Appendix B), indicates locations of highest air concentrations for emissions from each PNNL Site major emission unit. The CAP88-PC model uses the appropriate meteorological data (see Section 4.5) and emission unit characteristics (see Section 4.4).

Output from the CAP88-PC dispersion modeling was evaluated to determine the location of maximum expected radionuclide concentration as well as the concentrations predicted at each of the potential MEI locations identified in Section 5.2. Based on that assessment, the highest potential air concentrations would occur in three general directions-SSE/S, NW, and NE/NNE. Those directions also correspond to the sectors toward which the wind blows with the highest frequency (Section 4.5, Table 4.7). For all major emission units, the highest onsite $X / Q$ values were calculated at a distance of 100 to $200 \mathrm{~m}$ in the NW sector (see Appendix B), which currently corresponds to unoccupied locations within the PNNL Site boundary. The highest calculated X/Q for the Section 5.2 receptor facilities was $530 \mathrm{~m}$ SSE from the 3410 stack, near NSB $\left(1.48 \mathrm{E}-6 \mathrm{~s} / \mathrm{m}^{3}\right)$. The $\mathrm{X} / \mathrm{Q}$ at that location is $84 \%$ of the $\mathrm{X} / \mathrm{Q}$ calculated for the stack at $100 \mathrm{~m} \mathrm{NW}$.

The criteria for determining the ideal location for the air monitoring station to determine MEI impacts were based on the following:

- The "occupied” offsite location of highest air concentrations from PSF emissions. For the purposes of this evaluation, "occupied” was defined as an offsite location that might be frequented by a single individual. Locations of heavy traffic with no single individual highly impacted were excluded. See Section 4.8, Figure 4.2 and Figure 4.3.

- To maximize the capability to detect significant radioactive air emissions, locations where air concentrations would be expected to be at least $50 \%$ of the maximum were considered to be candidate sites for a new sampling station (see discussion in Section 4.8). However, the $50 \%$ value was found to be applicable to a wide area; therefore, a more conservative $65 \%$ value was selected to increase the capability to detect airborne radionuclides and to narrow the set of candidate sites.

In general, the modeling has determined that locations within $500 \mathrm{~m}$ and $1000 \mathrm{~m}$ of each PSF source in the S and SSE sectors satisfy those criteria and would provide data at a point close to the occupied potential MEI locations listed in Section 5.2. More detailed data are presented in Figure 6.1 through Figure 6.5.

Locations closer to the source facilities in the northerly directions, which have higher estimated air concentrations, are currently unoccupied and have no power supply. Establishing new air sampling stations to the north of the laboratory facilities would involve considerable time and expense.

Visual presentation of the data where the proposed MEI air monitoring station might be located is more readily understood than the data tabulations of Appendix B.

- Figure 6.1. The SE, SSE, and S sectors relative to each PSF major emission unit are shown. The air concentration (i.e., X/Q values) estimates were highest in the SSE sector for each of the three PNNL 
Site major emission units. The overlap of the SSE sectors from each emission unit is indicated by the hatch marks.

- Figure 6.2. Locations downwind of the 3410 Building that are at least $65 \%$ of the maximum air concentration location. The radial sector with the maximum air concentration was $530 \mathrm{~m}$ SSE for the 3410 Building.

- Figure 6.3. Locations downwind of the 3420 Building that are at least $65 \%$ of the maximum air concentration location. The radial sector with the maximum air concentration was $900 \mathrm{~m}$ SSE for the 3420 Building.

- Figure 6.4 Locations downwind of the 3430 Building that are at least $65 \%$ of the maximum air concentration location. The radial sector with the maximum air concentration was $800 \mathrm{~m}$ SSE for the 3430 Building.

- Figure 6.5. The overlap of the "65\% regions" of each of the three PSF facilities. The hatchmarks on this figure indicate the overlap of the hatch-marked areas of Figure 6.2 through Figure 6.4.

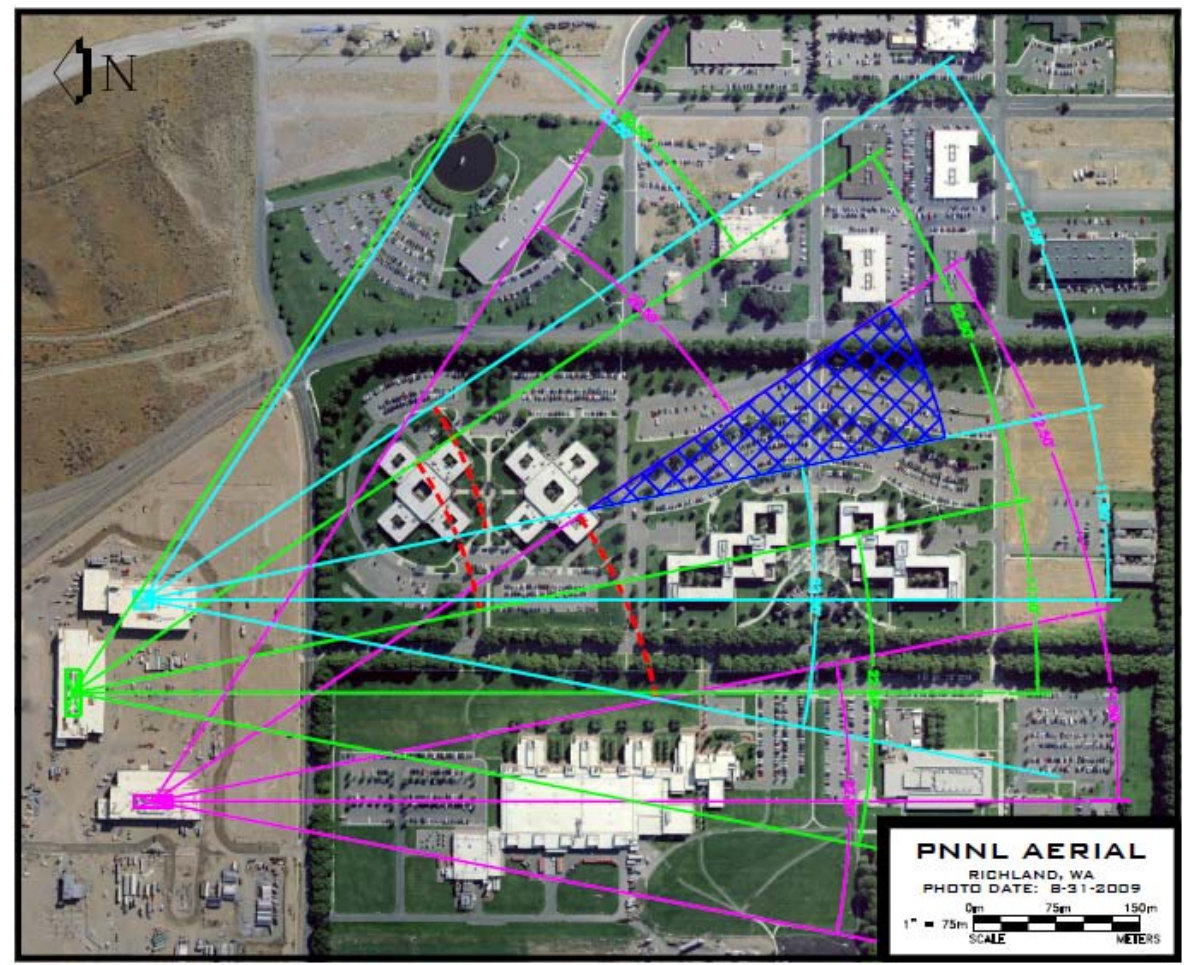

Figure 6.1. SE, SSE, and S Sectors from Emission Units. Hatch marks indicate overlap of SSE sector. 


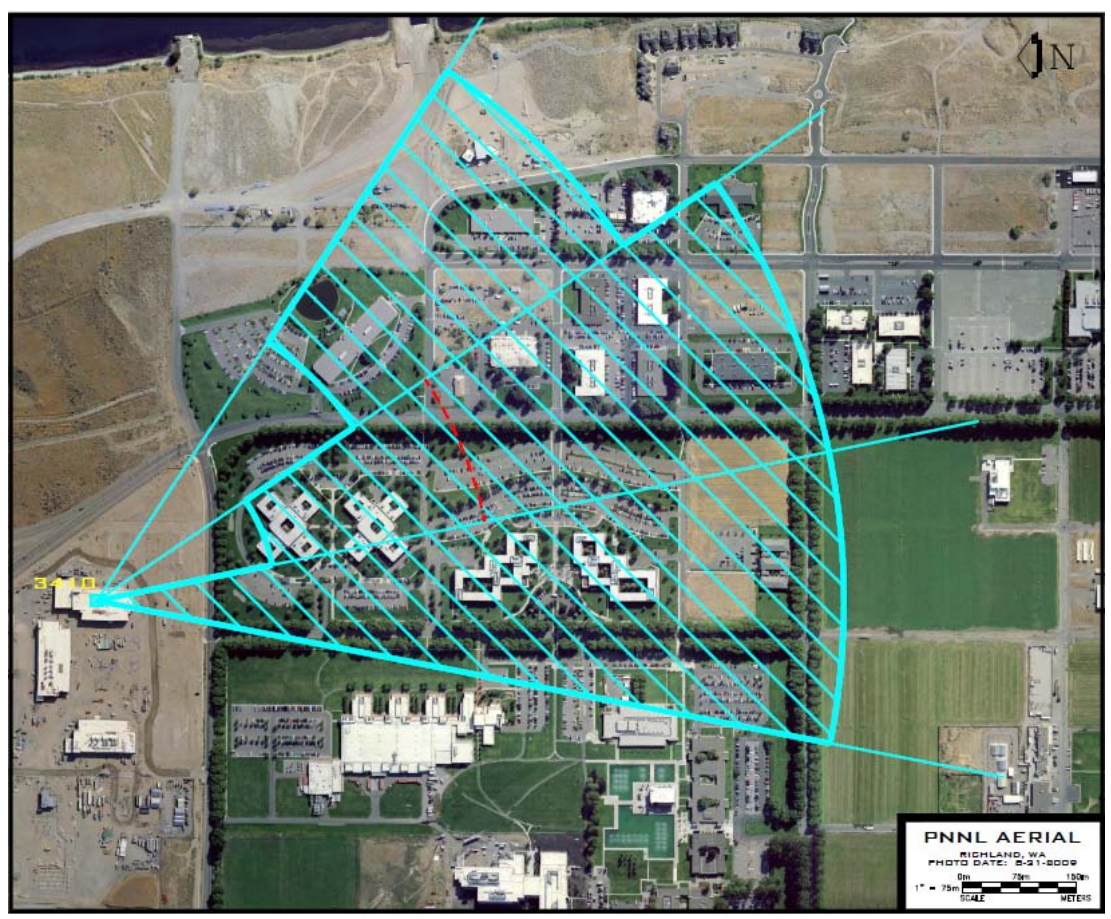

Figure 6.2. Locations Relative to the 3410 Building that Are at Least $65 \%$ of the Maximum Air Concentration

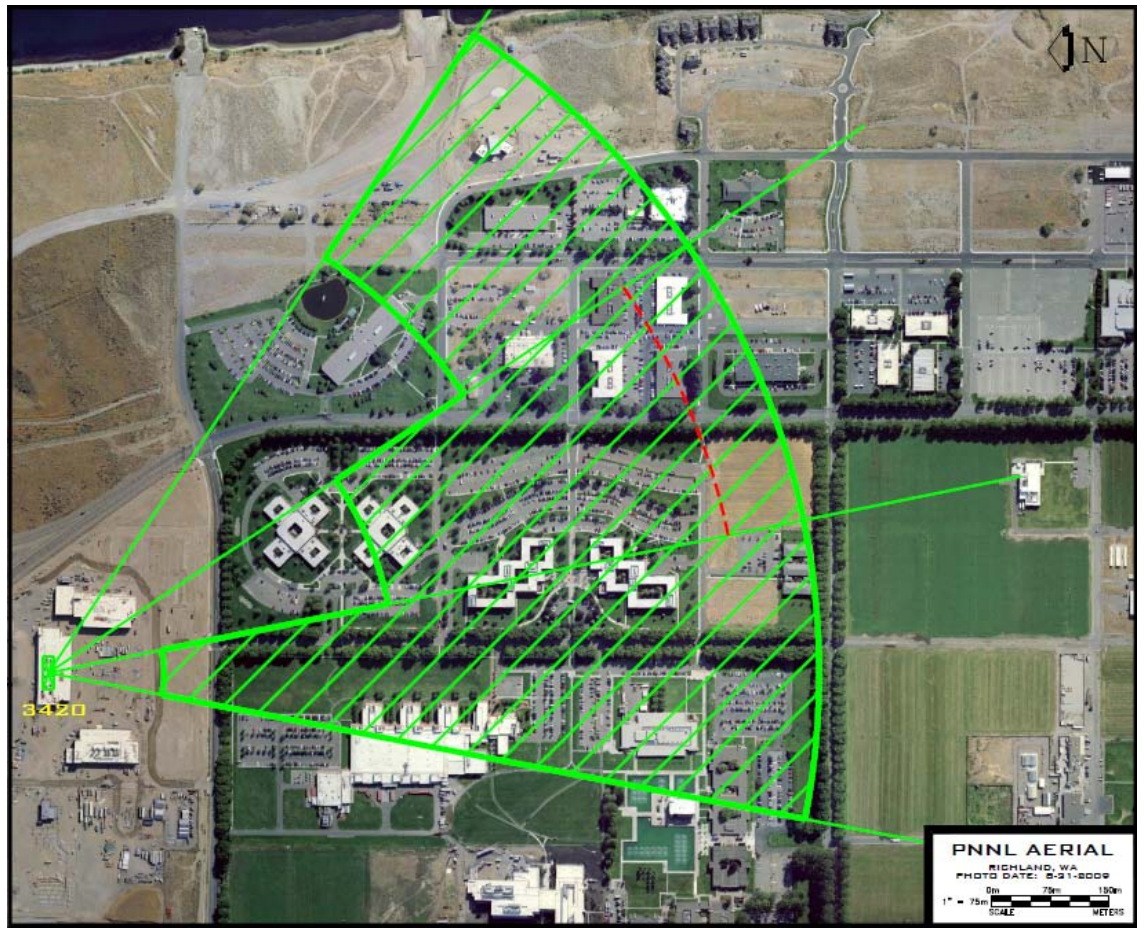

Figure 6.3. Locations Relative to the 3420 Building that Are at Least $65 \%$ of the Maximum Air Concentration 


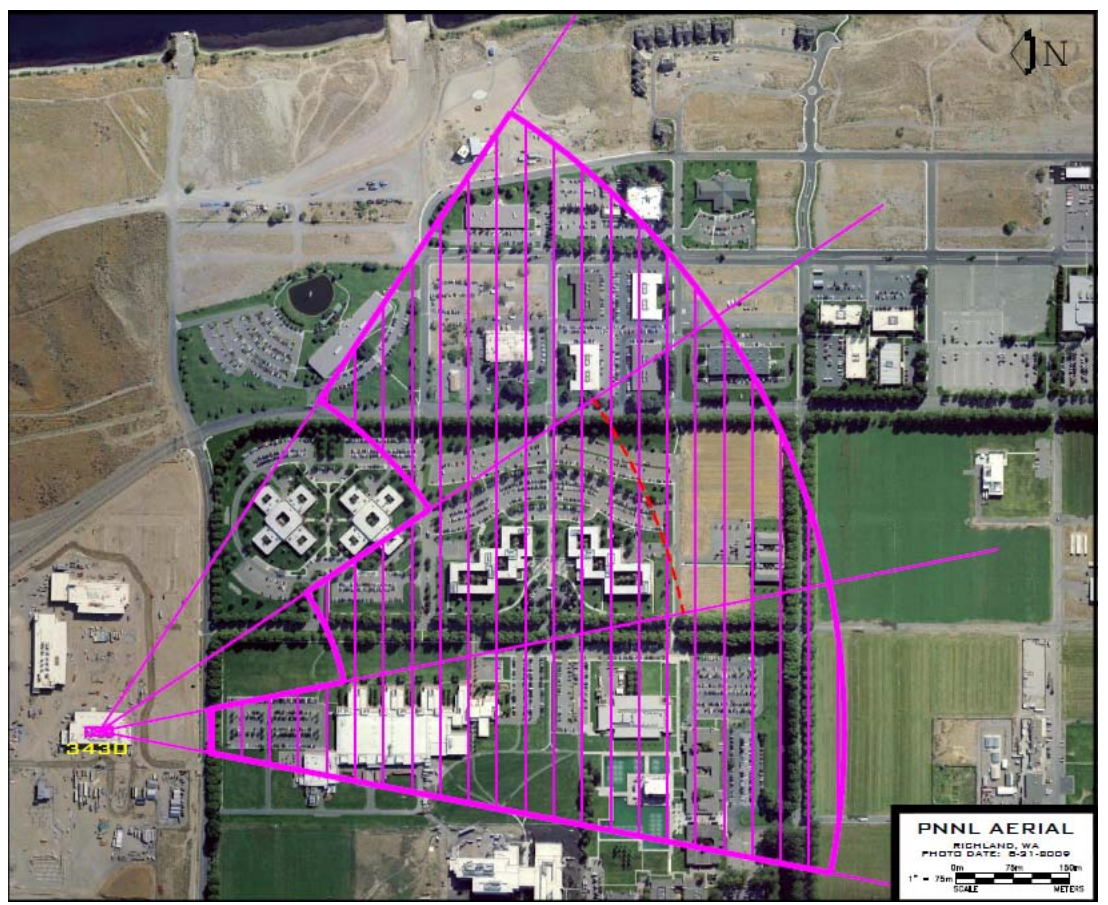

Figure 6.4. Locations Relative to the 3430 Building that Are at Least $65 \%$ of the Maximum Air Concentration

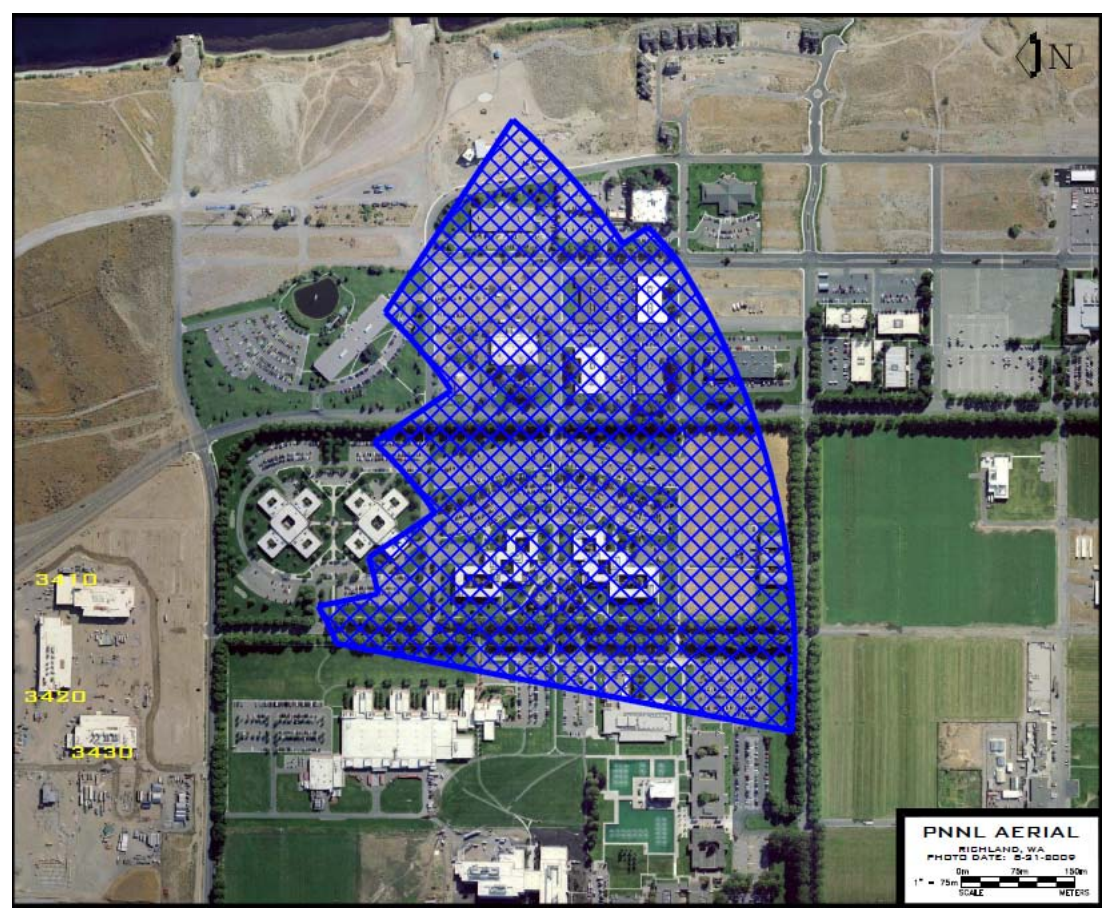

Figure 6.5. Overlap of the Three PSF Facility “65\% Regions” of the Previous Three Figures 
As an additional visual presentation of the data, Figure 6.6 presents the data shown in Figure 4.2 with additional data refinement. Figure 4.2 presented X/Q ratios for the dominant air concentration contributor, the 3410 Building, for all distances and directions when the ratios were greater than $50 \%$. Figure 6.6 presents the 3410 Building air concentration ratios $65 \%$ and greater that are beyond the PNNL Site fence line in the indicated direction. From this figure, the relationship of the maximum fenceline air concentration ratio to the $480 \mathrm{~m}$ SSE location ratio can be seen.

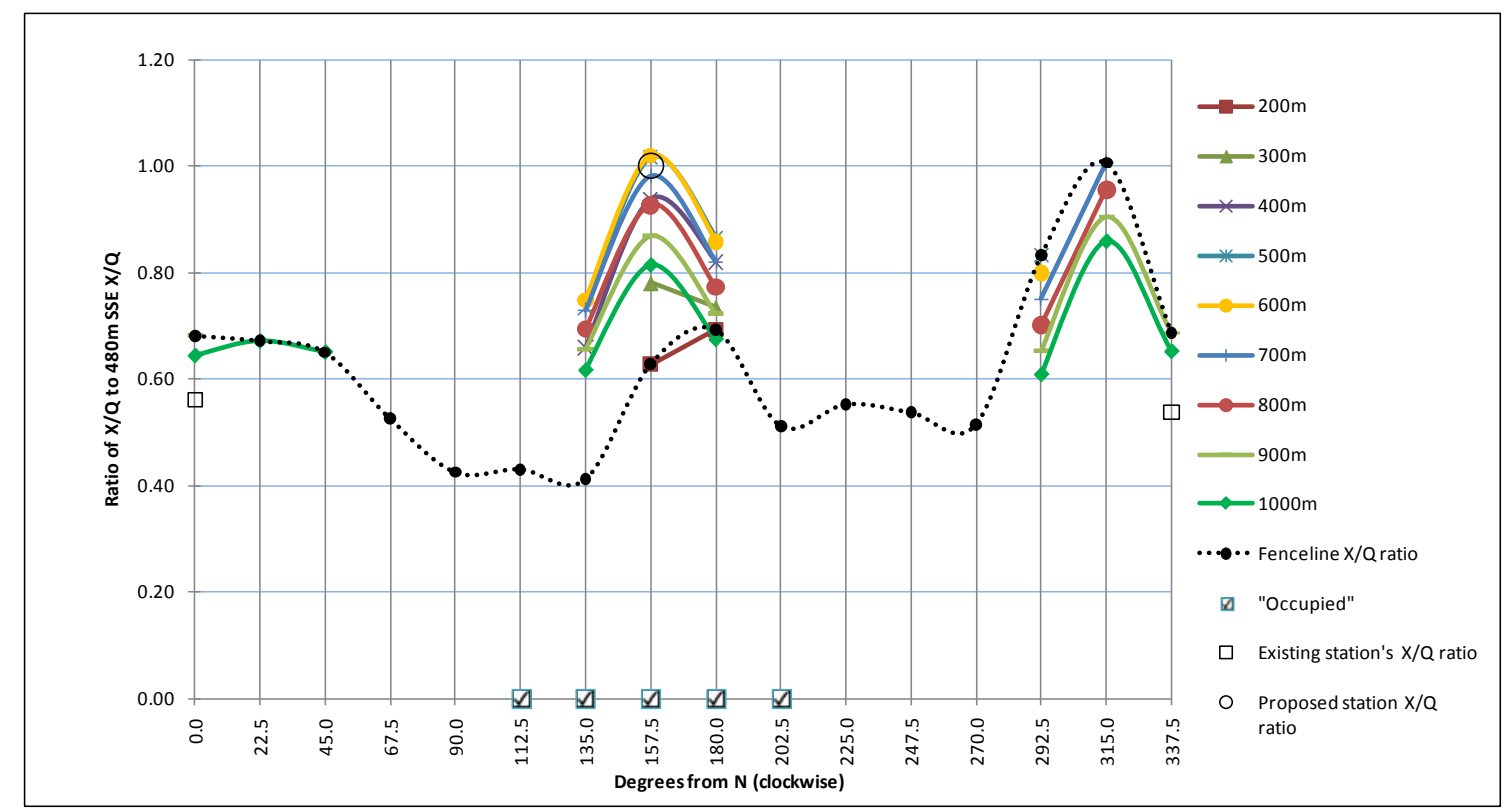

Figure 6.6. Air Concentration Ratios of Indicated Location to the Maximum Location (480 m SSE of 3410) when 65\% or Greater AND Beyond the PNNL Site Fenceline

Given practical considerations (see Section 5.4) and the information presented in Figure 6.5 and Figure 6.6, the DQO team has proposed that the MEI monitoring station be sited about $480 \mathrm{~m}$ SSE of the 3410 Building emission unit (see Figure 6.7) at light pole \#811. This location would best capture air emissions from each of the three PNNL Site major emission units at the highest expected concentrations. 


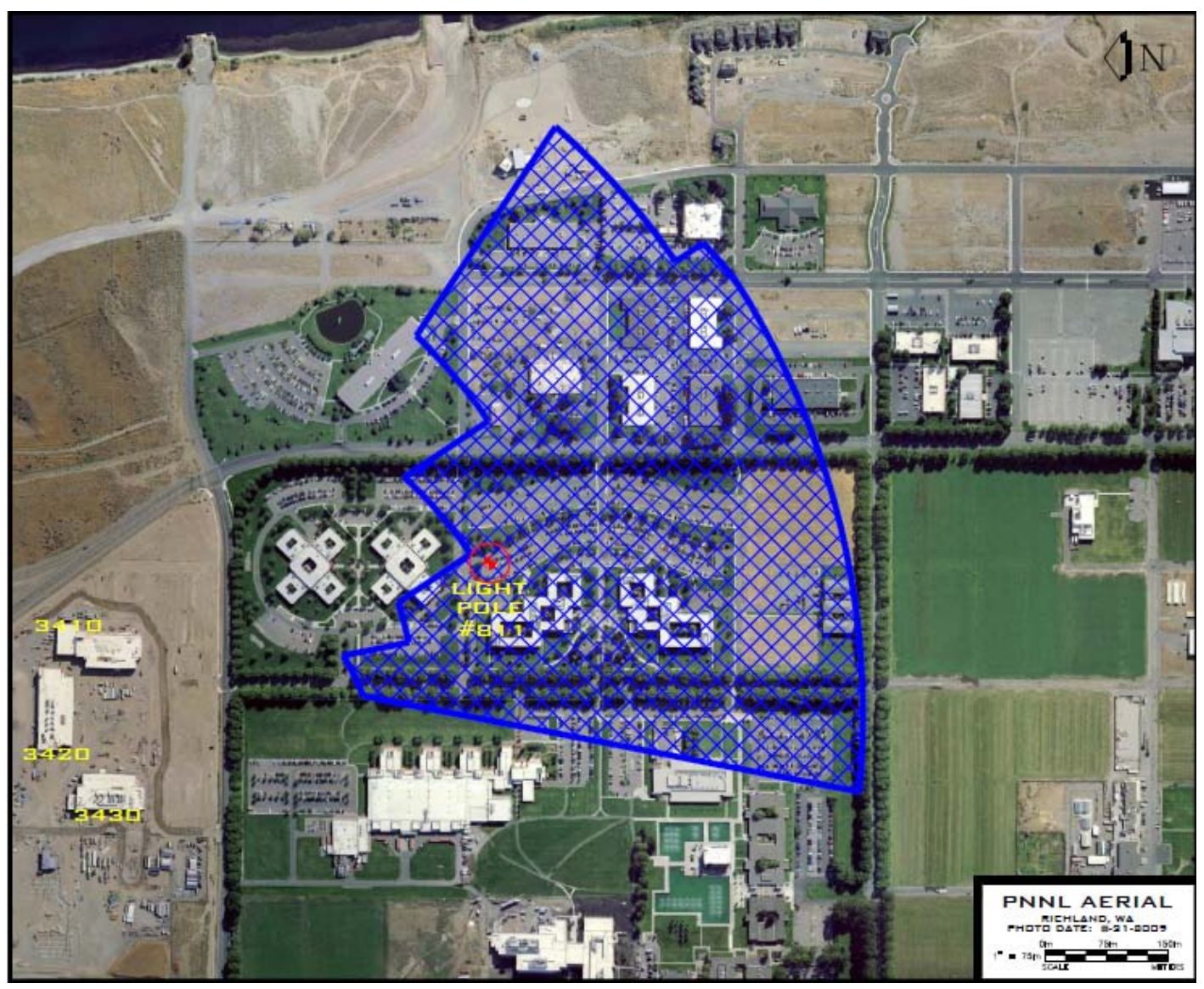

Figure 6.7. Circle Indicates the Location of the Proposed Monitoring Station (480 m SSE of 3410)

Decision \#4: Based on the estimated X/Q values as well as other constraints identified previously, a location 480 m SSE of the PSF 3410 Building emission unit (near PNNL's NSB Building) was proposed as the location for a new MEI air sampling station.

\subsection{Decision \#5}

\section{Question \#5: What environmental media should be monitored for the effects of radioactive air emissions?}

Action \#5: Determine which environmental media should be included in the proposed sampling program.

The air pathway is the only pathway that could contribute a significant dose to the hypothetical MEI that necessitates monitoring. The water at the MEI location originates from the Columbia Rivera and is supplied by the City of Richland. If necessary, concentrations of radionuclides in drinking water at the MEI location could be obtained from the SESP. PNNL will contribute an extremely small amount of emissions to the contaminant load of the Columbia River, and it will be impossible to differentiate these from background levels of radionuclides in the Columbia River. Since the MEI location is a work location (not a residence), the food pathway is not a possible exposure pathway. Additionally, no food is grown around the PNNL site. Inhaling re-suspended dust containing PNNL Site emissions that had 
deposited on the ground is a potential exposure pathway. However, atmospheric monitoring will provide a more realistic means of evaluating this pathway than soil monitoring would. The only pathway that will be necessary to monitor is the atmospheric pathway. Further, since the emissions from the PNNL Site are all particulates, only particulate monitoring will be necessary. No monitoring of gaseous radionuclides is necessary.

Decision \#5: Establish an environmental monitoring program that samples particulate radionuclides in air.

\subsection{Decision \#6}

\section{Question \#6: What are the requirements for an adequate radioactive air monitoring program?}

Action \#6: Past precedents have established the basic WDOH requirements for air monitoring networks for the Hanford Site. Existing air permits, consequently, provide a template for developing an air monitoring program for the PNNL site. An acceptable program must adhere to the basic guidance provided in DOE/EH-0173T (DOE 1991), meet the regulatory requirements regarding QA, provide operating coverage (temporal and spatial), and detect radionuclides-of-concern at concentrations meeting the regulatory requirements of WAC-246-247. To meet these requirements and, particularly, to have the ability to detect radionuclides-of-concern, the operating parameters of the sampling equipment and compositing schemes of samples must be evaluated. These are addressed in more detail in Chapter 8 .

Decision \#6: Define an air monitoring network using two air monitoring stations co-located with stations that have been established under the SESP and a new station situated near the NSB. Develop an environmental monitoring plan (including the sampling and analysis plan) based on the NOCs and negotiations with the WDOH and implement that program.

\subsection{Decision \#7}

Question \#7: Are there non-PNNL monitoring programs on or near the site that could be useful in design/implementation of the PNNL Site monitoring plan?

Action \#7: Identify what aspects of non-PNNL monitoring programs would be usable by the PNNL Site monitoring program; consider results, procedures, locations, and equipment.

DOE collects environmental monitoring data for the Hanford Site with a network operated by the SESP. There are also a number of commercial operations, such as Energy Northwest, that conduct environmental monitoring in the vicinity of the Hanford Site and the PNNL Site. Of those programs, the existing SESP Hanford network has several established monitoring locations that may be suitable to verify emissions from the PNNL Site. Although none of those stations correspond to the PSF MEI location, there are two existing stations in predominantly downwind directions where there would be a reasonable probability of detecting emissions from the PNNL Site. In addition, the long-established SESP monitoring procedures meet the requirements for an adequate radioactive air monitoring program as described in Question \#6. Therefore, the sampling methodology and procedures used by the SESP would be appropriate for use in a monitoring program established at the PNNL Site. Information for radionuclides sampled as part of the SESP monitoring program would also be useful as supplementary 
data for interpretation and comparison with the PNNL Site data. However, data from the SESP would not be suitable for use as primary compliance data because SESP samples are not currently analyzed for all radionuclides-of-concern for the PNNL site.

The established SESP monitoring stations are located in the N and NNW sectors, which are not within the region identified for the PNNL Site MEI as indicated in Figure 6.5 and Figure 6.6. Although the existing stations to the $\mathrm{N}$ and NNW are about $1.2 \mathrm{~km}$ from the PSF, the modeled X/Q values at those stations are about half the modeled X/Q for the PNNL Site MEI, and there are no other potential public receptors between those sampling locations and the PNNL facilities. Therefore, the established locations in the N and NNW sectors should provide adequate supplemental detection capability for radionuclide emissions from the PNNL Site. A third existing station is located about $1.4 \mathrm{~km}$ in the S/SSW direction, but the modeled X/Q at that location is lower, making it less desirable for use as a PNNL Site monitoring station.

Co-locating with the two existing SESP monitoring locations N and NNW of the PSF to confirm PNNL Site emissions would provide additional information from the more probable wind directions at minimal cost because co-locating PNNL sample stations could make use of established infrastructure, such as power and access. Data collected previously by the SESP establishes an extensive history of radionuclide sampling at those locations, and the new stations would provide duplicate sampling capability for isotopes that are included in both the Hanford Site and the PNNL Site monitoring programs.

Decision \#7: Two existing SESP monitoring locations N and NNW of the PSF should be used to establish new supplementary monitoring stations for the PNNL Site. The equipment, procedures, and analytical methods employed by the SESP would be suitable to provide adequate monitoring capability for the PNNL Site program, with minor modifications to provide analyses for all PNNL Site radionuclides-of-concern. 


\subsection{Decision Error Assessment}

Chapter 7 of the DQO report discusses the possibility that a wrong decision has been made in Chapter 6 and what the possible consequences would be.

For DQOs that include sampling data, these decision error assessments are normally done statistically. For the purpose of this DQO to select the appropriate air monitoring stations, the decision error assessment is done in an essay style format.

\subsection{Decision \#1 Error}

The radionuclides-of-concern that have been identified from the permitting process are particulate forms of ${ }^{241} \mathrm{Am},{ }^{243} \mathrm{Am},{ }^{244} \mathrm{Cm},{ }^{60} \mathrm{Co},{ }^{238} \mathrm{Pu},{ }^{239} \mathrm{Pu}$, and ${ }^{233} \mathrm{U}$.

The radionuclides-of-concern have been established based on the inventory mix (i.e., the annual possession quantities) of radionuclides identified in the permit applications. Normal operations at these research laboratories may result in a different mix of actual radionuclides that would be monitored at their point source; however, these would have to be less than the $0.1 \mathrm{mrem} / \mathrm{yr}$ PTE criteria, even though they may be in actual inventory at greater than $10 \%$ or even possibly emitted at greater than $25 \%$ with controls. There is a potential for a major permit application revision to contain new radionuclides meeting the requirements identified in Section 4.2, thereby resulting in the need for possible additional and/or different offsite sampling. A change in the list of radionuclides-of-concern should not affect the overall emission characteristics (e.g., meteorological data, monitoring location(s), and dispersion modeling). The mechanism is in the permitting process and triggers a change in the sampling and monitoring plan to allow and account for a change to the list of radionuclides-of-concern.

The consequence of an incorrect list of radionuclides will require a change in the analyses required so that they are included. These changes will be identified through the permitting process of the major emission units. Documentation could be through the annual radioactive air emission report required under both state and federal regulations (WAC 2005 and 40 CFR 61).

\subsection{Decision \#2 Error}

Using only major emission units and their emission characteristics, model the radionuclide releases based on current EPA-approved air dispersion codes.

Between PNNL Site major and minor emission units, the major emission units generate the greatest offsite impacts. The air permitting process requires the applicant to determine the major and minor emission units, which are assessed based on offsite impacts. The impact measurement is the dose to the maximally impacted receptor from routine operations. If an error were made in the decision to use the major emission unit releases for guiding the environmental surveillance program development for the PNNL Site, then the applicability of EPA's system of major and minor emission unit classifications would be called into question. The potential for under-reporting of offsite impacts would exist only if a major emission unit was not identified. This is unlikely as building radioactive material inventory is 
controlled by the Radioactive Material Tracking System, and major emission unit releases are measured through continuous stack sampling.

\subsection{Decision \#3 Error}

A chronic release rate of radionuclides-of-concern can be used for modeling release and exposure (i.e., dose). Normal facility operations as currently planned are not expected to result in significant acute releases of radioactive materials. If either planned or unanticipated short-term releases occur at the facilities, the need for alternative assessment methods would be evaluated.

With respect to exposure scenario estimate errors: CAP88 models uniform release and uniform exposure over the entire year. The MEI exposure and intake rates are greatly overestimated in the CAP88 evaluations. In addition, if it were the case that, in reality, all inventory were released in a short period of time, during the remainder of the year, the realistic exposure could be zero. Modeling of such acute releases with a chronic model would likely be equivalent or conservative (i.e., overestimated) depending on the realistic exposure factors.

The radionuclides-of-concern from both major and minor/diffuse emission units were evaluated for both unabated and abated impacts for this DQO. For this decision, errors would result from problems with inventory and exposure scenario estimates.

With respect to inventory estimate errors: Under environmental, safety, and health practices at PNNL, there are administrative controls in place to make certain that the annual inventory limits are not exceeded for each emission unit. These include the preparation of an annual PNNL Facility Radionuclide Assessment and the use of the PNNL Radioactive Materials Tracking System for day-to-day activities.

\subsection{Decision \#4 Error}

Based on the estimated X/Q values as well as other constraints identified previously, a location $480 \mathrm{~m}$ SSE of the PSF 3410 Building emission unit (near PNNL's NSB Building) was proposed as the most likely candidate for a new MEI air sampling station.

The proposed location was selected based on potential radionuclide release quantities, emission unit operations parameters, atmospheric modeling using site-specific meteorology collected over a long period of time, locations of occupied offsite facilities, and practical monitoring-station siting considerations.

To demonstrate compliance with the NESHAP dose standard, MEI impact estimates must be calculated annually. This calculation will use meteorology and release quantities (either measured or conservatively estimated) from major emission units for the reporting year. As available, environmental surveillance program particulate sampling results from the specific year of interest would be used to confirm compliance with the standard.

Given the conservative assumptions that went into each step of the process, the dose impact estimates calculated in CAP88-PC for the proposed new sampling location would likely overestimate any actual impacts received by an MEI. However, it is conceivable that given the inherent uncertainty in weather, a given year may have meteorology such that modeling indicates that the MEI is in a different location. In 
such a case, the meteorology from the specific year of interest and the measured emission rates from PNNL Site facilities would be used to determine that year's MEI location, and the dose for the alternate location would be calculated to demonstrate compliance with the standard. Although the MEI location for a given year may differ slightly from the location selected for environmental monitoring, atmospheric dispersion conditions are sufficiently consistent from year to year that air concentrations at the sampling station should still be detectable to confirm compliance with the dose standard.

The location of the proposed MEI monitoring station was based on the estimated offsite air concentrations from the dominant PSF facility (the 3410 Building). Table 7.1 indicates the X/Q at the proposed location from all three PSF major emission units. ${ }^{a}$

Table 7.1. Chi-over-Q values from All Major Emission Units for the Proposed Location

\begin{tabular}{ccc}
\hline Radioisotope & Proposed Location & $\mathrm{X} / \mathrm{Q}\left(\mathrm{s} / \mathrm{m}^{3}\right)$ \\
\hline 3410 Building & $480 \mathrm{~m} \mathrm{SSE}$ & $1.44 \mathrm{E}-6$ \\
3420 Building & $570 \mathrm{~m}$ SSE & $4.66 \mathrm{E}-7$ \\
3430 Building & $545 \mathrm{~m}$ SSE & $7.59 \mathrm{E}-7$ \\
\hline Total & & $2.66 \mathrm{E}-6$ \\
\hline
\end{tabular}

If other changes occur that might affect sample collection or results from the proposed air monitoring station, their effect on the capability to detect potentially significant radionuclide air emissions from the PNNL Site would be re-evaluated. Such events might include changes in operations at the PSF (e.g., major facility modifications or altered radionuclide inventories), construction of new offsite facilities in the vicinity of the PNNL Site, and other activities near the proposed monitoring station. As circumstances required, the station could be relocated in response to those external events.

\subsection{Decision \#5 Error}

Establish an environmental monitoring program that samples particulate radionuclides in air.

All possible exposure routes were discussed in Section 6.5. No potential errors can be identified based on anticipated operations described in the NOCs. If operations at the PNNL Site were to change, such that types of radionuclides not currently identified as significant contributors to offsite impacts were potentially emitted from the facilities, the need for changes to the sampling program could be re-evaluated and implemented as necessary.

\subsection{Decision \#6 Error}

Define an air monitoring network using two air monitoring stations co-located with stations that have been established under the SESP and a new station situated near the NSB. Develop an environmental

(a) The potential-to-emit document (Rhoads and Barnett 2009) indicates that the maximum location (170 m SSE) $\mathrm{X} / \mathrm{Q}$ is $1.55 \mathrm{E}-5 \mathrm{sec} / \mathrm{m}^{3}$. Therefore, the alternative baseline assumptions that were used in that earlier document remain conservative (i.e., doses estimated from use of the Rhoads and Barnett (2009) over-estimate actual anticipated dose to the MEI). Therefore, Rhoads and Barnett (2009) does not need to be updated based on the results of this DQO. 
monitoring plan (including the sampling and analysis plan), based on the NOCs and negotiations with the WDOH, and implement the program.

Based on the very well documented wind patterns in the 300 Area and the PNNL site, the likelihood that three sampling locations are inadequate is very low. The potential for increased risk is further diminished by the presence of the Hanford Site air monitoring and surveillance network. With the present inventory of radiological materials and uses at the PNNL Site at the expected release rates, there is a large and significant margin of safety such that the public is not at undue risk, and the design is adequate and can stand alone.

\subsection{Decision \#7 Error}

Two existing SESP monitoring locations $\mathrm{N}$ and NNW of the PSF should be used to establish new supplementary monitoring stations for the PNNL Site. The equipment, procedures, and analytical methods employed by the SESP would be suitable to provide adequate monitoring capability for the PNNL Site program, with minor modifications to provide analyses for all PNNL Site radionuclides-ofconcern.

There could be a potential error associated with this decision if the SESP monitoring program is not found to meet the criteria for an "acceptable" air monitoring program. In this scenario, the PNNL Site monitoring program would be modified to meet the criteria. Revisions to the PNNL Site program could include having to rewrite procedures or modify the collection and analytical methodologies. 


\subsection{Optimization Guidelines}

The WDOH administers an air permit for radiological air releases at the Hanford Site, the much larger DOE site located adjacent to the PNNL Site. The SESP operates an air monitoring network in support of the Hanford Site Air Operating permit (i.e., AIR-10-308). The monitoring network is compliant with the requirements of that permit. The methods and equipment used on that program are also compatible with expected requirements for the PNNL Site. Two existing SESP air sampling stations in the 300 Area (see Figure 2.1) have been identified in the DQO as meeting the needs of the air monitoring program for the PNNL Site. Separate sampling hutches will be established at these locations. A third station will be added (proposed at: $480 \mathrm{~m}$ SSE of the 3410 Building) to complete the sampling configuration and indicate the most elevated air concentrations from PSF emissions. The particulate sampling equipment of this third station would match the design and operation of the particulate samplers presently in use on the Hanford Site.

\subsection{Sampling Equipment}

Particulate samplers presently in use on the Hanford Site are air particulate samplers consisting of a filter head followed by an air volume meter, flow controller, and ultimately a $115 \mathrm{~V} 1 / 4 \mathrm{HP}$ vacuum pump (Gast VS23-0523CV, or equivalent). The sampling system is contained in a sampling hutch requiring 115-volt and 20-amp service. The procedures used for maintaining and collecting samples are reported in Hanf et al. (2007). The system uses 2-in. glass fiber filters (LB-5511, RADECO, or equivalent) that are collected every two weeks. Flow rates through the filter head are set at $2.0 \mathrm{cfm}$ to make certain that detection levels are achieved. The total volume of air sampled over the two week period is $1150 \mathrm{~m}^{3}$. The 2-week samples are analyzed for gross alpha and gross beta and then fed into quarterly composite samples for the 13-week quarter. Radionuclide analyses are performed on quarterly composite samples at each location. This is done to meet analytical detection limits and the performance requirements of the permit. Such actions would also meet the sample collection and analysis needs for the PNNL Site.

\subsection{Analytical Detection Limits}

Particulate air samples are submitted to an analytical laboratory under contract to PNNL for all radiological analyses. The analytical contract will require a modification for the analysis of ${ }^{233} \mathrm{U}$ and the addition of ${ }^{243} \mathrm{Am}$.

Existing air monitoring programs that operate under a notification system whereby WDOH is notified when an air monitoring station concentration result meets or exceeds $10 \%$ of the Table 2 value of 40 CFR 61, Appendix E (see examples of Notification Values in Table 8.1) were evaluated to determine a required detection limit (RDL). The capability of a monitoring program to meet these notification requirements can be assessed by comparing contractual RDLs and the nominal mean achieved minimum detectable activity (MDA) with the reporting levels (i.e., notification values of Table 8.1). The mean achieved detectable activity is provided by the contracting laboratory, and it reflects the average achieved detection limit for a particular assay. For this DQO, nominal mean MDAs were only available for ${ }^{60} \mathrm{Co}$,

${ }^{238} \mathrm{Pu}$, and ${ }^{239} \mathrm{Pu}$ (see Nominal Mean MDA of 2008 in Table 8.1). 
Air data were obtained from the Hanford Environmental Information System (HEIS) for all air samples with ${ }^{241} \mathrm{Am},{ }^{243} \mathrm{Am},{ }^{244} \mathrm{Cm},{ }^{60} \mathrm{Co},{ }^{238} \mathrm{Pu},{ }^{239,240} \mathrm{Pu},{ }^{234} \mathrm{U}$, and ${ }^{238} \mathrm{U}$ results. Americium-241 results were derived from gamma spectroscopy, and the MDA does not meet the reporting requirements in WAC 246-247. The mean MDA for ${ }^{241} \mathrm{Am}$ with gamma spectroscopy is approximately $3.0 \mathrm{E}-3 \mathrm{pCi} / \mathrm{m}^{3}$. In calendar year 2010, ${ }^{241} \mathrm{Am}$ analysis in air particulate matter samples was performed with alpha spectroscopy. Using alpha spectroscopy, the mean achieved detectable activity is expected to decrease to $1.0 \mathrm{E}-5 \mathrm{pCi} / \mathrm{m}^{3}$ and would meet the objectives of the PNNL Site air program. Americium-243 will be included in the alpha spectroscopy analysis along with ${ }^{241} \mathrm{Am}$. The detection limits for ${ }^{243} \mathrm{Am}$ would be on the order of $1.0 \mathrm{E}-5 \mathrm{pCi} / \mathrm{m}^{3}$ and meet the detection requirements.

There is no operational history for ${ }^{244} \mathrm{Cm}$ in air particulate matter sampling of the SESP. Because ${ }^{244} \mathrm{Cm}$ is an alpha emitter, the detection limits are expected to approach $1.0 \mathrm{E}-5 \mathrm{pCi} / \mathrm{m}^{3}$, thus meeting the detection requirements. The nominal detection limits for ${ }^{60} \mathrm{Co},{ }^{238} \mathrm{Pu}$, and ${ }^{239,240} \mathrm{Pu}$ meet the detection requirements. There are no data for ${ }^{233} \mathrm{U}$ because alpha spectroscopy cannot distinguish between alpha decay energies for ${ }^{233} U$ and ${ }^{234} U$. For ${ }^{233} U$, a uranium isotopic analysis will be requested for ${ }^{233,234} U,{ }^{235} U$, and ${ }^{238} \mathrm{U}$. The activity associated with ${ }^{233,234} \mathrm{U}$ will be compared to ${ }^{238} \mathrm{U}$ activity, and if the ratio exceeds 1.15, the sample will be subjected to mass spectroscopy. A modification to the analytical subcontract will be required for mass spectroscopy on uranium sample residues. For samples where the ratio is between 1.0 and 1.15, the results will be flagged as having no potential for ${ }^{233} \mathrm{U}$ present.

There is a degree of uncertainty with the capability to detect ${ }^{241} \mathrm{Am},{ }^{243} \mathrm{Am},{ }^{244} \mathrm{Cm}$, and ${ }^{233} \mathrm{U}$. Cobalt-60 is right at the level of detection required for notification. The data in HEIS includes the result, the contractual RDL, the achieved MDA, and the amount of air sampled for a particular result. One 2-week sample filter generally represents two weeks of sampling and $856 \mathrm{~m}^{3}$ of air. To meet lower detection limits, sample filters are composited over time and among stations deployed in the same general geographical location. Pumps will be operated at $2.0 \mathrm{cfm}$ to make certain that an adequate amount of air is sampled to meet the regulatory notification requirements. A single location composited over the course of one annual quarter (13 weeks) such that a much larger sample volume is analyzed will result in lower detection levels and may be necessary to meet the DQO sampling objectives. After a year of data collection, the compositing and filter head configuration design can be reviewed and modified if necessary. 40 CFR 61, Appendix E contains an assessment of MDAs vs. sample volume that clearly demonstrate the relationship between the volume of air sampled and MDAs for ${ }^{241} \mathrm{Am}$ (by gamma spectroscopy), ${ }^{60} \mathrm{Co},{ }^{238} \mathrm{Pu},{ }^{239,240} \mathrm{Pu}$, and ${ }^{238} \mathrm{U}$. One filter head composited with biweekly samples will result in $5600 \mathrm{~m}^{3}$; this volume doubles when two filter heads are used, essentially doubling the volume of air sampled.

The notification values are all higher than the RDLs except for the $10 \%$ value of ${ }^{60} \mathrm{Co}$. In this case, the mean detection levels are considerably lower than the RDL and would accommodate the $10 \%$ reporting level. 
Table 8.1. Analytical Detection Limit Comparison to Notification Values

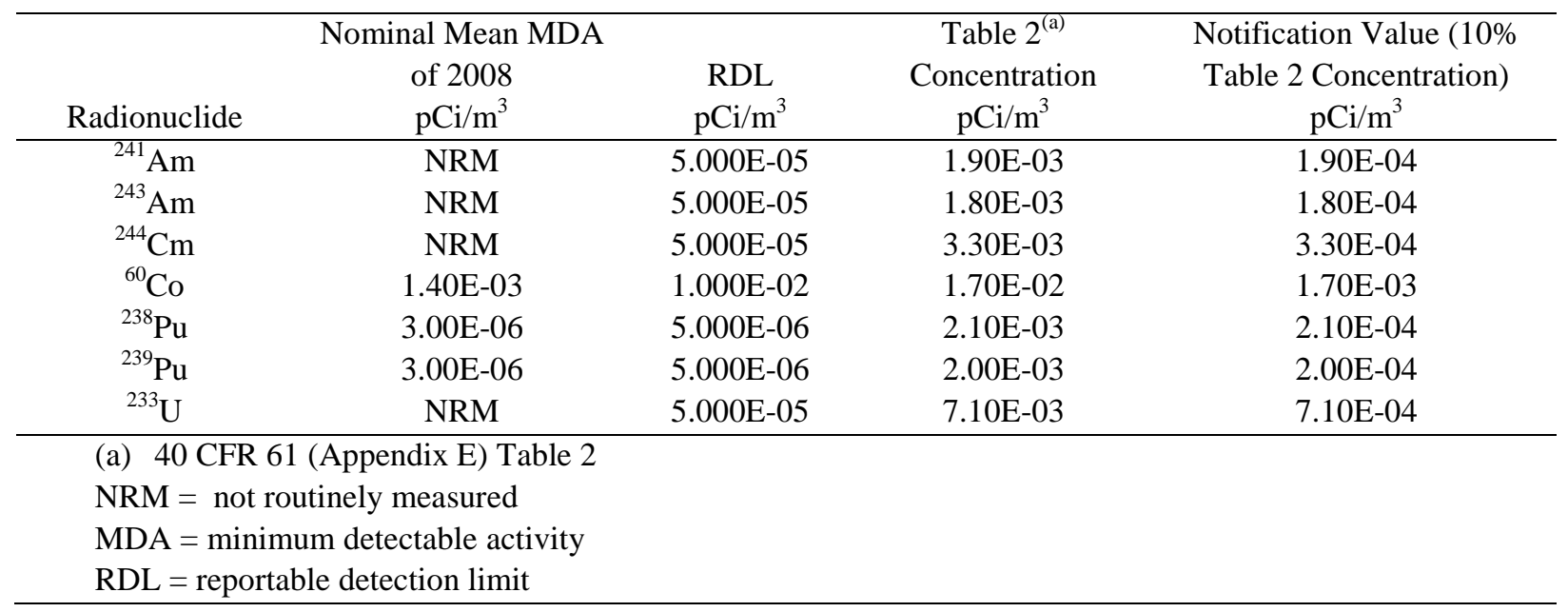




\subsection{References}

40 CFR Part 61, Subpart H. 2002. "National Emission Standards for Radionuclides Other Than Radon From Department of Energy Facilities.” U.S. Code of Federal Regulations, U.S. Environmental Protection Agency.

ANSI-American National Standards Institute. 1999. Sampling and Monitoring Releases of Airborne Radioactive Substances From the Stack and Ducts of Nuclear Facilities. ANSI/HPS N13.1-1999, Health Physics Society, McLean, Virginia.

DOE-U.S. Department of Energy. 1991. Environmental Regulatory Guide for Radiological Effluent Monitoring and Environmental Surveillance. DOE/EH-0173T. DOE, Washington, D.C.

Duncan JP (ed), KW Burk, MA Chamness, RA Fowler, BG Fritz, PL Hendrickson, EP Kennedy, GV Last, TM Poston, MR Sackschewsky, MJ Scott, SF Snyder, MD Sweeney, and PD Thorne . 2007. Hanford Site National Environmental Policy Act (NEPA) Characterization. PNNL-6415 Rev. 18, Pacific Northwest National Laboratory, Richland, Washington.

EPA-U.S. Environmental Protection Agency. 2006. Guidance on Systematic Planning Using the Data Quality Objective Process (EPA QA/G-4). EPA/240/B-06/001, Office of Environmental Information, Washington, D.C.

Hanf RW, TM Poston, and LE Bisping. 2007. PNNL Administrative/Technical Procedures Surface Environmental Surveillance Procedures Manual, PNL-MA-580, Rev. 5. PNNL-16744, Pacific Northwest National Laboratory, Richland, Washington.

Hoitink DJ, KW Burk, JV Ramsdell, and WJ Shaw. 2005. Hanford Site Climatological Data Summary Calendar Year 2004 with Historical Data. PNNL-15160, Pacific Northwest National Laboratory, Richland, Washington. Online at: http://hanford-site.pnl.gov/envreport/2004/15160.htm

ICRP_International Commission on Radiological Protection. 1983. Radionuclide Transformations, Energy and Intensity of Emissions. ICRP Publication 38, Volumes 11-13. Pergamon Press, New York.

Napier BA, DL Strenge, JV Ramsdell Jr., PW Eslinger, and C Fosmire. 2008. GENII Version 2 Software Design Document. PNNL-14584, Rev. 2c, Pacific Northwest National Laboratory, Richland, Washington.

PNNL_Pacific Northwest National Laboratory. 2007. PNNL Potential Impact Categories, Rev 2. Effluent Management, Richland, Washington.

Poston TM, JP Duncan, and RL Dirkes. 2009. Hanford Site Environmental Report for Calendar Year 2008. PNNL-18427, Pacific Northwest National Laboratory, Richland, Washington.

Rhoads K and JM Barnett. 2009. PNNL Site Dose-per-Unit-Release Factors for Use in Calculating Radionuclide Air Emissions Potential-to-Emit Doses.CRL-TECH-ESH-007, Rev. 1. PNNL-17847, Rev. 1, Pacific Northwest National Laboratory, Richland, Washington. 
Rosnick RJ. 2007. CAP88-PC Version 3.0 User Guide. Office of Radiation and Indoor Air, U.S. Environmental Protection Agency, Washington D.C.

Washington Administrative Code. 2005. Radiation Protection - Air Emissions. WAC 246-247, Statute Law Committee, Washington State, Olympia, Washington. 
Appendix A

Meteorological Data 


\section{Appendix A: Meteorological Data}

The table below contains Joint Frequency Distributions of Atmospheric Stability, Wind Speed, and Transport Direction for the 300 Area at $9.1 \mathrm{~m}$ (30 ft) above Ground Level, Hanford Site, Washington. This is based on 1983-2006 data from the 300 Area instrumented tower (Duncan (ed) et al. 2007).

\begin{tabular}{|c|c|c|c|c|c|c|c|c|c|c|c|c|c|c|c|c|c|}
\hline \multirow{2}{*}{$\begin{array}{c}\text { Average } \\
\text { Wind Speed }\end{array}$} & $\begin{array}{c}\text { Atmospheric } \\
\text { Stability Class }\end{array}$ & \multicolumn{16}{|c|}{ ercentage of Time Wind Blows in the 300 Area toward the Direction Indicated } \\
\hline & $9.1 \mathrm{~m}$ & S & SSW & SW & WSW & $\mathrm{W}$ & WNW & NW & NNW & $\mathrm{N}$ & NNE & $\mathrm{NE}$ & ENE & $\mathrm{E}$ & ESE & SE & SSE \\
\hline \multirow{7}{*}{$\begin{array}{l}0.89 \mathrm{~m} / \mathrm{s} \\
(2 \mathrm{mph})\end{array}$} & A & 0.07 & 0.07 & 0.09 & 0.11 & 0.11 & 0.11 & 0.12 & 0.10 & 0.07 & 0.05 & 0.05 & 0.04 & 0.04 & 0.04 & 0.06 & 0.07 \\
\hline & B & 0.05 & 0.04 & 0.04 & 0.04 & 0.05 & 0.05 & 0.06 & 0.05 & 0.04 & 0.03 & 0.03 & 0.03 & 0.03 & 0.03 & 0.04 & 0.05 \\
\hline & C & 0.04 & 0.03 & 0.04 & 0.04 & 0.04 & 0.05 & 0.06 & 0.05 & 0.04 & 0.04 & 0.02 & 0.02 & 0.03 & 0.02 & 0.03 & 0.05 \\
\hline & D & 0.33 & 0.20 & 0.17 & 0.18 & 0.21 & 0.34 & 0.38 & 0.37 & 0.34 & 0.32 & 0.29 & 0.26 & 0.28 & 0.28 & 0.40 & 0.45 \\
\hline & E & 0.35 & 0.20 & 0.14 & 0.13 & 0.20 & 0.35 & 0.50 & 0.54 & 0.55 & 0.46 & 0.43 & 0.39 & 0.42 & 0.46 & 0.54 & 0.49 \\
\hline & $\mathrm{F}$ & 0.28 & 0.17 & 0.12 & 0.09 & 0.16 & 0.28 & 0.49 & 0.53 & 0.49 & 0.37 & 0.35 & 0.30 & 0.31 & 0.38 & 0.50 & 0.46 \\
\hline & G & 0.16 & 0.08 & 0.05 & 0.05 & 0.07 & 0.11 & 0.19 & 0.21 & 0.20 & 0.14 & 0.15 & 0.12 & 0.13 & 0.17 & 0.24 & 0.22 \\
\hline \multirow{7}{*}{$\begin{array}{l}2.65 \mathrm{~m} / \mathrm{s} \\
(6 \mathrm{mph})\end{array}$} & A & 0.24 & 0.32 & 0.41 & 0.50 & 0.67 & 0.67 & 0.62 & 0.30 & 0.27 & 0.34 & 0.29 & 0.15 & 0.08 & 0.05 & 0.08 & 0.17 \\
\hline & B & 0.13 & 0.14 & 0.12 & 0.14 & 0.19 & 0.21 & 0.27 & 0.15 & 0.11 & 0.13 & 0.12 & 0.06 & 0.03 & 0.02 & 0.04 & 0.12 \\
\hline & C & 0.12 & 0.11 & 0.10 & 0.11 & 0.14 & 0.18 & 0.21 & 0.11 & 0.10 & 0.11 & 0.09 & 0.04 & 0.02 & 0.02 & 0.06 & 0.11 \\
\hline & D & 0.96 & 0.49 & 0.31 & 0.31 & 0.51 & 0.96 & 1.31 & 0.69 & 0.63 & 0.64 & 0.51 & 0.33 & 0.22 & 0.23 & 0.57 & 1.10 \\
\hline & E & 1.09 & 0.34 & 0.08 & 0.09 & 0.23 & 1.13 & 1.81 & 1.07 & 1.01 & 0.75 & 0.59 & 0.42 & 0.35 & 0.39 & 0.69 & 1.23 \\
\hline & $\mathrm{F}$ & 0.66 & 0.16 & 0.03 & 0.02 & 0.09 & 1.01 & 1.98 & 1.02 & 0.69 & 0.43 & 0.24 & 0.13 & 0.13 & 0.17 & 0.43 & 0.82 \\
\hline & G & 0.27 & 0.06 & 0.01 & 0.01 & 0.03 & 0.33 & 0.79 & 0.38 & 0.21 & 0.11 & 0.06 & 0.03 & 0.03 & 0.05 & 0.19 & 0.36 \\
\hline \multirow{7}{*}{$\begin{array}{c}4.7 \mathrm{~m} / \mathrm{s} \\
(10.5 \mathrm{mph})\end{array}$} & A & 0.28 & 0.57 & 0.42 & 0.11 & 0.15 & 0.30 & 0.34 & 0.15 & 0.25 & 0.62 & 0.66 & 0.29 & 0.08 & 0.06 & 0.09 & 0.15 \\
\hline & B & 0.12 & 0.16 & 0.08 & 0.03 & 0.03 & 0.08 & 0.10 & 0.05 & 0.09 & 0.21 & 0.22 & 0.11 & 0.04 & 0.02 & 0.04 & 0.09 \\
\hline & C & 0.11 & 0.11 & 0.06 & 0.03 & 0.02 & 0.05 & 0.08 & 0.04 & 0.07 & 0.16 & 0.18 & 0.08 & 0.02 & 0.01 & 0.04 & 0.08 \\
\hline & D & 0.74 & 0.41 & 0.20 & 0.07 & 0.09 & 0.22 & 0.39 & 0.24 & 0.42 & 0.88 & 0.88 & 0.48 & 0.18 & 0.14 & 0.44 & 0.87 \\
\hline & $\mathrm{E}$ & 1.07 & 0.34 & 0.05 & 0.03 & 0.04 & 0.25 & 0.34 & 0.24 & 0.51 & 0.85 & 0.91 & 0.48 & 0.21 & 0.17 & 0.38 & 0.79 \\
\hline & $\mathrm{F}$ & 0.74 & 0.22 & 0.02 & 0.02 & 0.02 & 0.26 & 0.30 & 0.11 & 0.25 & 0.38 & 0.34 & 0.14 & 0.03 & 0.02 & 0.07 & 0.40 \\
\hline & G & 0.36 & 0.10 & 0.00 & 0.00 & 0.01 & 0.14 & 0.18 & 0.04 & 0.07 & 0.10 & 0.08 & 0.03 & 0.01 & 0.00 & 0.02 & 0.16 \\
\hline \multirow{7}{*}{$\begin{array}{c}7.2 \mathrm{~m} / \mathrm{s} \\
(16 \mathrm{mph})\end{array}$} & A & 0.12 & 0.19 & 0.05 & 0.00 & 0.00 & 0.00 & 0.02 & 0.01 & 0.06 & 0.34 & 0.56 & 0.41 & 0.11 & 0.05 & 0.10 & 0.08 \\
\hline & B & 0.04 & 0.04 & 0.01 & 0.00 & 0.00 & 0.00 & 0.01 & 0.00 & 0.02 & 0.11 & 0.16 & 0.10 & 0.03 & 0.01 & 0.03 & 0.05 \\
\hline & C & 0.03 & 0.02 & 0.01 & 0.00 & 0.00 & 0.00 & 0.01 & 0.00 & 0.02 & 0.09 & 0.14 & 0.08 & 0.02 & 0.01 & 0.03 & 0.04 \\
\hline & D & 0.16 & 0.10 & 0.03 & 0.01 & 0.00 & 0.01 & 0.04 & 0.04 & 0.14 & 0.49 & 0.69 & 0.38 & 0.15 & 0.08 & 0.39 & 0.42 \\
\hline & $\mathrm{E}$ & 0.13 & 0.07 & 0.03 & 0.02 & 0.01 & 0.01 & 0.04 & 0.04 & 0.10 & 0.36 & 0.64 & 0.26 & 0.09 & 0.05 & 0.29 & 0.29 \\
\hline & $\mathrm{F}$ & 0.06 & 0.03 & 0.02 & 0.02 & 0.00 & 0.00 & 0.00 & 0.01 & 0.02 & 0.08 & 0.17 & 0.05 & 0.01 & 0.00 & 0.01 & 0.05 \\
\hline & G & 0.03 & 0.02 & 0.00 & 0.00 & 0.00 & 0.00 & 0.00 & 0.00 & 0.01 & 0.04 & 0.05 & 0.01 & 0.00 & 0.00 & 0.00 & 0.01 \\
\hline \multirow{7}{*}{$\begin{array}{c}9.8 \mathrm{~m} / \mathrm{s} \\
(22 \mathrm{mph})\end{array}$} & A & 0.01 & 0.02 & 0.00 & 0.00 & 0.00 & 0.00 & 0.00 & 0.00 & 0.01 & 0.09 & 0.16 & 0.17 & 0.07 & 0.02 & 0.04 & 0.02 \\
\hline & B & 0.01 & 0.01 & 0.00 & 0.00 & 0.00 & 0.00 & 0.00 & 0.00 & 0.00 & 0.02 & 0.05 & 0.04 & 0.02 & 0.00 & 0.01 & 0.01 \\
\hline & C & 0.00 & 0.00 & 0.00 & 0.00 & 0.00 & 0.00 & 0.00 & 0.00 & 0.00 & 0.02 & 0.04 & 0.04 & 0.01 & 0.00 & 0.02 & 0.01 \\
\hline & D & 0.02 & 0.02 & 0.01 & 0.00 & 0.00 & 0.00 & 0.00 & 0.01 & 0.03 & 0.15 & 0.29 & 0.14 & 0.07 & 0.02 & 0.16 & 0.08 \\
\hline & E & 0.01 & 0.04 & 0.02 & 0.01 & 0.00 & 0.00 & 0.00 & 0.01 & 0.02 & 0.11 & 0.28 & 0.06 & 0.02 & 0.01 & 0.08 & 0.04 \\
\hline & D & 0.00 & 0.00 & 0.00 & 0.00 & 0.00 & 0.00 & 0.00 & 0.00 & 0.00 & 0.01 & 0.04 & 0.00 & 0.00 & 0.00 & 0.00 & 0.00 \\
\hline & G & 0.00 & 0.00 & 0.00 & 0.00 & 0.00 & 0.00 & 0.00 & 0.00 & 0.00 & 0.01 & 0.02 & 0.00 & 0.00 & 0.00 & 0.00 & 0.00 \\
\hline \multirow{7}{*}{$\begin{array}{c}12.7 \mathrm{~m} / \mathrm{s} \\
(29 \mathrm{mph})\end{array}$} & A & 0.00 & 0.00 & 0.00 & 0.00 & 0.00 & 0.00 & 0.00 & 0.00 & 0.00 & 0.01 & 0.05 & 0.04 & 0.02 & 0.00 & 0.01 & 0.00 \\
\hline & B & 0.00 & 0.00 & 0.00 & 0.00 & 0.00 & 0.00 & 0.00 & 0.00 & 0.00 & 0.00 & 0.02 & 0.01 & 0.00 & 0.00 & 0.00 & 0.00 \\
\hline & C & 0.00 & 0.00 & 0.00 & 0.00 & 0.00 & 0.00 & 0.00 & 0.00 & 0.00 & 0.00 & 0.02 & 0.01 & 0.00 & 0.00 & 0.00 & 0.00 \\
\hline & D & 0.01 & 0.01 & 0.00 & 0.00 & 0.00 & 0.00 & 0.00 & 0.00 & 0.00 & 0.05 & 0.17 & 0.04 & 0.02 & 0.01 & 0.03 & 0.01 \\
\hline & $\mathrm{E}$ & 0.00 & 0.01 & 0.00 & 0.00 & 0.00 & 0.00 & 0.00 & 0.00 & 0.00 & 0.04 & 0.11 & 0.01 & 0.01 & 0.00 & 0.02 & 0.00 \\
\hline & $\mathrm{F}$ & 0.00 & 0.00 & 0.00 & 0.00 & 0.00 & 0.00 & 0.00 & 0.00 & 0.00 & 0.00 & 0.01 & 0.00 & 0.00 & 0.00 & 0.00 & 0.00 \\
\hline & $\mathrm{G}$ & 0.00 & 0.00 & 0.00 & 0.00 & 0.00 & 0.00 & 0.00 & 0.00 & 0.00 & 0.00 & 0.01 & 0.00 & 0.00 & 0.00 & 0.00 & 0.00 \\
\hline
\end{tabular}




\begin{tabular}{|c|c|c|c|c|c|c|c|c|c|c|c|c|c|c|c|c|c|}
\hline \multirow{2}{*}{$\begin{array}{c}\text { Average } \\
\text { Wind Speed }\end{array}$} & $\begin{array}{l}\text { Atmospheric } \\
\text { Stability Class }\end{array}$ & \multicolumn{16}{|c|}{ Percentage of Time Wind Blows in the 300 Area toward the Direction Indicated } \\
\hline & $9.1 \mathrm{~m}$ & S & SSW & SW & WSW & W & WNW & NW & NNW & $\mathrm{N}$ & NNE & $\mathrm{NE}$ & ENE & $E$ & ESE & SE & SSE \\
\hline \multirow{7}{*}{$\begin{array}{c}15.6 \mathrm{~m} / \mathrm{s} \\
(35 \mathrm{mph})\end{array}$} & A & 0.00 & 0.00 & 0.00 & 0.00 & 0.00 & 0.00 & 0.00 & 0.00 & 0.00 & 0.00 & 0.01 & 0.00 & 0.00 & 0.00 & 0.00 & 0.00 \\
\hline & B & 0.00 & 0.00 & 0.00 & 0.00 & 0.00 & 0.00 & 0.00 & 0.00 & 0.00 & 0.00 & 0.00 & 0.00 & 0.00 & 0.00 & 0.00 & 0.00 \\
\hline & C & 0.00 & 0.00 & 0.00 & 0.00 & 0.00 & 0.00 & 0.00 & 0.00 & 0.00 & 0.00 & 0.01 & 0.00 & 0.00 & 0.00 & 0.00 & 0.00 \\
\hline & D & 0.00 & 0.00 & 0.00 & 0.00 & 0.00 & 0.00 & 0.00 & 0.00 & 0.00 & 0.01 & 0.04 & 0.01 & 0.01 & 0.00 & 0.00 & 0.00 \\
\hline & E & 0.00 & 0.00 & 0.00 & 0.00 & 0.00 & 0.00 & 0.00 & 0.00 & 0.00 & 0.01 & 0.02 & 0.00 & 0.00 & 0.00 & 0.00 & 0.00 \\
\hline & $\mathrm{F}$ & 0.00 & 0.00 & 0.00 & 0.00 & 0.00 & 0.00 & 0.00 & 0.00 & 0.00 & 0.00 & 0.00 & 0.00 & 0.00 & 0.00 & 0.00 & 0.00 \\
\hline & G & 0.00 & 0.00 & 0.00 & 0.00 & 0.00 & 0.00 & 0.00 & 0.00 & 0.00 & 0.00 & 0.00 & 0.00 & 0.00 & 0.00 & 0.00 & 0.00 \\
\hline \multirow{7}{*}{$\begin{array}{c}19 \mathrm{~m} / \mathrm{s} \\
\text { (43 mph) }\end{array}$} & A & 0.00 & 0.00 & 0.00 & 0.00 & 0.00 & 0.00 & 0.00 & 0.00 & 0.00 & 0.00 & 0.00 & 0.00 & 0.00 & 0.00 & 0.00 & 0.00 \\
\hline & B & 0.00 & 0.00 & 0.00 & 0.00 & 0.00 & 0.00 & 0.00 & 0.00 & 0.00 & 0.00 & 0.00 & 0.00 & 0.00 & 0.00 & 0.00 & 0.00 \\
\hline & C & 0.00 & 0.00 & 0.00 & 0.00 & 0.00 & 0.00 & 0.00 & 0.00 & 0.00 & 0.00 & 0.00 & 0.00 & 0.00 & 0.00 & 0.00 & 0.00 \\
\hline & D & 0.00 & 0.00 & 0.00 & 0.00 & 0.00 & 0.00 & 0.00 & 0.00 & 0.00 & 0.00 & 0.01 & 0.00 & 0.00 & 0.00 & 0.00 & 0.00 \\
\hline & E & 0.00 & 0.00 & 0.00 & 0.00 & 0.00 & 0.00 & 0.00 & 0.00 & 0.00 & 0.00 & 0.01 & 0.00 & 0.00 & 0.00 & 0.00 & 0.00 \\
\hline & $\mathrm{F}$ & 0.00 & 0.00 & 0.00 & 0.00 & 0.00 & 0.00 & 0.00 & 0.00 & 0.00 & 0.00 & 0.00 & 0.00 & 0.00 & 0.00 & 0.00 & 0.00 \\
\hline & G & 0.00 & 0.00 & 0.00 & 0.00 & 0.00 & 0.00 & 0.00 & 0.00 & 0.00 & 0.00 & 0.00 & 0.00 & 0.00 & 0.00 & 0.00 & 0.00 \\
\hline
\end{tabular}


Appendix B

\section{Chi-over-Q Tables}




\section{Appendix B: Chi-over-Q Tables}

Table B.1. Chi/Q $\left(\mathrm{sec} / \mathrm{m}^{3}\right)$ for 3410 Building Stack Parameters-Effective Stack Height with Buoyant and Momentum Plume Rise................................................................................

Table B.2. Chi/Q $\left(\mathrm{sec} / \mathrm{m}^{3}\right.$ ) for 3420 Building Stack Parameters-Effective Stack Height with Buoyant and Momentum Plume Rise...

Table B.3. Chi/Q $\left(\mathrm{sec} / \mathrm{m}^{3}\right)$ for 3430 Building Stack Parameters-Effective Stack Height with Buoyant and Momentum Plume Rise.. B. 4 
Table B.1. Chi/Q (sec/ $\mathrm{m}^{3}$ ) for 3410 Building Stack Parameters_Effective Stack Height with Buoyant and Momentum Plume Rise

\begin{tabular}{|c|c|c|c|c|c|c|c|c|c|c|c|c|c|c|}
\hline \multirow[b]{2}{*}{ Direction } & \multicolumn{14}{|c|}{ Distance (meters) } \\
\hline & 100 & 200 & 300 & 400 & 500 & 600 & 700 & 800 & 900 & 1000 & 1500 & 2000 & 5000 & 10000 \\
\hline $\mathrm{N}$ & $9.61 \mathrm{E}-07$ & 8.88E-07 & 9.03E-07 & $1.02 \mathrm{E}-06$ & $1.10 \mathrm{E}-06$ & $1.11 \mathrm{E}-06$ & 1.08E-06 & $1.04 \mathrm{E}-06$ & 9.83E-07 & $9.29 \mathrm{E}-07$ & $6.71 \mathrm{E}-07$ & 5.07E-07 & $1.78 \mathrm{E}-07$ & $7.94 \mathrm{E}-08$ \\
\hline NNW & $1.04 \mathrm{E}-06$ & $9.67 \mathrm{E}-07$ & $9.56 \mathrm{E}-07$ & 1.05E-06 & $1.12 \mathrm{E}-06$ & $1.12 \mathrm{E}-06$ & $1.09 \mathrm{E}-06$ & $1.04 \mathrm{E}-06$ & $9.90 \mathrm{E}-07$ & $9.41 \mathrm{E}-07$ & $6.91 \mathrm{E}-07$ & $5.28 \mathrm{E}-07$ & $1.90 \mathrm{E}-07$ & $8.62 \mathrm{E}-08$ \\
\hline NW & $1.75 \mathrm{E}-06$ & $1.55 \mathrm{E}-06$ & $1.44 \mathrm{E}-06$ & $1.50 \mathrm{E}-06$ & $1.54 \mathrm{E}-06$ & $1.51 \mathrm{E}-06$ & $1.45 \mathrm{E}-06$ & 1.38E-06 & $1.31 \mathrm{E}-06$ & $1.24 \mathrm{E}-06$ & $9.06 \mathrm{E}-07$ & $6.92 \mathrm{E}-07$ & $2.50 \mathrm{E}-07$ & $1.14 \mathrm{E}-07$ \\
\hline WNW & $1.71 \mathrm{E}-06$ & $1.41 \mathrm{E}-06$ & 1.23E-06 & $1.21 \mathrm{E}-06$ & $1.20 \mathrm{E}-06$ & $1.15 \mathrm{E}-06$ & $1.08 \mathrm{E}-06$ & $1.01 \mathrm{E}-06$ & $9.42 \mathrm{E}-07$ & 8.79E-07 & $6.16 \mathrm{E}-07$ & 4.59E-07 & $1.58 \mathrm{E}-07$ & $7.01 \mathrm{E}-08$ \\
\hline W & 1.59E-06 & $1.25 \mathrm{E}-06$ & $9.56 \mathrm{E}-07$ & $8.29 \mathrm{E}-07$ & 7.43E-07 & $6.66 \mathrm{E}-07$ & 5.96E-07 & 5.34E-07 & $4.80 \mathrm{E}-07$ & 4.35E-07 & $2.80 \mathrm{E}-07$ & $1.98 \mathrm{E}-07$ & $6.24 \mathrm{E}-08$ & $2.68 \mathrm{E}-08$ \\
\hline WSW & $1.31 \mathrm{E}-06$ & $1.02 \mathrm{E}-06$ & 7.75E-07 & $6.55 \mathrm{E}-07$ & $5.71 \mathrm{E}-07$ & $5.00 \mathrm{E}-07$ & 4.39E-07 & 3.87E-07 & $3.44 \mathrm{E}-07$ & $3.08 \mathrm{E}-07$ & $1.91 \mathrm{E}-07$ & $1.33 \mathrm{E}-07$ & $4.00 \mathrm{E}-08$ & $1.70 \mathrm{E}-08$ \\
\hline SW & 1.34E-06 & 1.05E-06 & 7.97E-07 & $6.75 \mathrm{E}-07$ & $5.90 \mathrm{E}-07$ & 5.18E-07 & 4.56E-07 & 4.04E-07 & 3.60E-07 & 3.23E-07 & 2.04E-07 & 1.43E-07 & 4.42E-08 & $1.88 \mathrm{E}-08$ \\
\hline SSW & 1.37E-06 & $1.14 \mathrm{E}-06$ & $9.29 \mathrm{E}-07$ & 8.54E-07 & $8.00 \mathrm{E}-07$ & 7.38E-07 & $6.74 \mathrm{E}-07$ & $6.14 \mathrm{E}-07$ & 5.59E-07 & $5.11 \mathrm{E}-07$ & 3.39E-07 & 2.44E-07 & 7.93E-08 & $3.45 \mathrm{E}-08$ \\
\hline S & $1.01 \mathrm{E}-06$ & $9.99 \mathrm{E}-07$ & $1.06 \mathrm{E}-06$ & $1.18 \mathrm{E}-06$ & $1.25 \mathrm{E}-06$ & $1.24 \mathrm{E}-06$ & $1.18 \mathrm{E}-06$ & 1.11E-06 & $1.04 \mathrm{E}-06$ & 9.73E-07 & $6.79 \mathrm{E}-07$ & 5.03E-07 & $1.72 \mathrm{E}-07$ & 7.66E-08 \\
\hline SSE & 7.93E-07 & $9.05 \mathrm{E}-07$ & 1.13E-06 & 1.35E-06 & $1.47 \mathrm{E}-06$ & $1.47 \mathrm{E}-06$ & $1.42 \mathrm{E}-06$ & 1.34E-06 & 1.25E-06 & 1.17E-06 & 8.25E-07 & $6.14 \mathrm{E}-07$ & 2.11E-07 & $9.36 \mathrm{E}-08$ \\
\hline SE & 5.54E-07 & 5.94E-07 & 7.63E-07 & $9.51 \mathrm{E}-07$ & $1.06 \mathrm{E}-06$ & $1.08 \mathrm{E}-06$ & $1.05 \mathrm{E}-06$ & $1.00 \mathrm{E}-06$ & $9.46 \mathrm{E}-07$ & 8.90E-07 & $6.34 \mathrm{E}-07$ & 4.75E-07 & 1.65E-07 & $7.40 \mathrm{E}-08$ \\
\hline ESE & 3.49E-07 & 3.52E-07 & $4.30 \mathrm{E}-07$ & $5.45 \mathrm{E}-07$ & $6.24 \mathrm{E}-07$ & 6.52E-07 & 6.45E-07 & $6.21 \mathrm{E}-07$ & 5.92E-07 & 5.61E-07 & 4.06E-07 & 3.06E-07 & $1.08 \mathrm{E}-07$ & $4.81 \mathrm{E}-08$ \\
\hline E & 4.65E-07 & 4.53E-07 & 5.02E-07 & 5.91E-07 & $6.50 \mathrm{E}-07$ & $6.62 \mathrm{E}-07$ & $6.44 \mathrm{E}-07$ & 6.13E-07 & 5.78E-07 & $5.42 \mathrm{E}-07$ & 3.82E-07 & $2.84 \mathrm{E}-07$ & $9.64 \mathrm{E}-08$ & 4.23E-08 \\
\hline ENE & $9.50 \mathrm{E}-07$ & 8.19E-07 & 7.74E-07 & $8.25 \mathrm{E}-07$ & 8.57E-07 & 8.47E-07 & 8.09E-07 & 7.59E-07 & 7.07E-07 & 6.57E-07 & $4.52 \mathrm{E}-07$ & 3.31E-07 & $1.10 \mathrm{E}-07$ & $4.74 \mathrm{E}-08$ \\
\hline $\mathrm{NE}$ & $1.59 \mathrm{E}-06$ & $1.34 \mathrm{E}-06$ & $1.21 \mathrm{E}-06$ & $1.25 \mathrm{E}-06$ & $1.27 \mathrm{E}-06$ & $1.24 \mathrm{E}-06$ & $1.17 \mathrm{E}-06$ & 1.09E-06 & $1.01 \mathrm{E}-06$ & $9.39 \mathrm{E}-07$ & $6.40 \mathrm{E}-07$ & 4.68E-07 & $1.54 \mathrm{E}-07$ & $6.65 \mathrm{E}-08$ \\
\hline NNE & $1.47 \mathrm{E}-06$ & $1.28 \mathrm{E}-06$ & $1.20 \mathrm{E}-06$ & $1.26 \mathrm{E}-06$ & $1.29 \mathrm{E}-06$ & $1.26 \mathrm{E}-06$ & $1.20 \mathrm{E}-06$ & 1.12E-06 & $1.04 \mathrm{E}-06$ & $9.69 \mathrm{E}-07$ & $6.68 \mathrm{E}-07$ & 4.92E-07 & $1.64 \mathrm{E}-07$ & $7.10 \mathrm{E}-08$ \\
\hline
\end{tabular}


Table B.2. Chi/Q $\left(\mathrm{sec} / \mathrm{m}^{3}\right)$ for 3420 Building Stack Parameters-Effective Stack Height with Buoyant and Momentum Plume Rise

\begin{tabular}{|c|c|c|c|c|c|c|c|c|c|c|c|c|c|c|}
\hline \multirow[b]{2}{*}{ Direction } & \multicolumn{14}{|c|}{ Distance (meters) } \\
\hline & 100 & 200 & 300 & 400 & 500 & 600 & 700 & 800 & 900 & 1000 & 1500 & 2000 & 5000 & 10000 \\
\hline $\mathrm{N}$ & $2.10 \mathrm{E}-07$ & $4.23 \mathrm{E}-07$ & $3.60 \mathrm{E}-07$ & $3.30 \mathrm{E}-07$ & $3.40 \mathrm{E}-07$ & $3.69 \mathrm{E}-07$ & 3.99E-07 & $4.21 \mathrm{E}-07$ & $4.33 \mathrm{E}-07$ & $4.35 \mathrm{E}-07$ & $3.61 \mathrm{E}-07$ & $3.00 \mathrm{E}-07$ & $1.28 \mathrm{E}-07$ & $5.99 \mathrm{E}-08$ \\
\hline NNW & $2.26 \mathrm{E}-07$ & 4.62E-07 & 3.94E-07 & 3.56E-07 & $3.60 \mathrm{E}-07$ & 3.84E-07 & 4.09E-07 & $4.28 \mathrm{E}-07$ & 4.37E-07 & 4.37E-07 & 3.63E-07 & 3.04E-07 & $1.34 \mathrm{E}-07$ & 6.35E-08 \\
\hline WNW & $3.81 \mathrm{E}-07$ & 7.32E-07 & $5.86 \mathrm{E}-07$ & 4.93E-07 & 4.62E-07 & 4.59E-07 & 4.62E-07 & 4.63E-07 & 4.57E-07 & 4.47E-07 & $3.48 \mathrm{E}-07$ & $2.81 \mathrm{E}-07$ & $1.15 \mathrm{E}-07$ & 5.32E-08 \\
\hline W & 3.56E-07 & $6.76 \mathrm{E}-07$ & 5.25E-07 & 4.16E-07 & 3.58E-07 & 3.27E-07 & $3.06 \mathrm{E}-07$ & 2.88E-07 & $2.72 \mathrm{E}-07$ & $2.55 \mathrm{E}-07$ & $1.80 \mathrm{E}-07$ & $1.36 \mathrm{E}-07$ & $4.84 \mathrm{E}-08$ & $2.14 \mathrm{E}-08$ \\
\hline WSW & 2.95E-07 & $5.55 \mathrm{E}-07$ & $4.32 \mathrm{E}-07$ & $3.41 \mathrm{E}-07$ & 2.91E-07 & $2.61 \mathrm{E}-07$ & 2.39E-07 & $2.22 \mathrm{E}-07$ & 2.06E-07 & $1.91 \mathrm{E}-07$ & $1.30 \mathrm{E}-07$ & $9.53 \mathrm{E}-08$ & $3.20 \mathrm{E}-08$ & $1.38 \mathrm{E}-08$ \\
\hline SW & 3.02E-07 & $5.70 \mathrm{E}-07$ & 4.43E-07 & $3.50 \mathrm{E}-07$ & 2.99E-07 & 2.69E-07 & $2.47 \mathrm{E}-07$ & $2.29 \mathrm{E}-07$ & 2.13E-07 & $1.98 \mathrm{E}-07$ & $1.35 \mathrm{E}-07$ & $1.00 \mathrm{E}-07$ & $3.47 \mathrm{E}-08$ & $1.52 \mathrm{E}-08$ \\
\hline SSW & 3.02E-07 & 5.93E-07 & 4.75E-07 & 3.89E-07 & 3.49E-07 & 3.30E-07 & $3.20 \mathrm{E}-07$ & 3.09E-07 & $2.98 \mathrm{E}-07$ & 2.84E-07 & 2.09E-07 & $1.61 \mathrm{E}-07$ & $6.02 \mathrm{E}-08$ & $2.70 \mathrm{E}-08$ \\
\hline S & $2.14 \mathrm{E}-07$ & 4.54E-07 & $4.02 \mathrm{E}-07$ & $3.80 \mathrm{E}-07$ & 3.99E-07 & $4.31 \mathrm{E}-07$ & $4.60 \mathrm{E}-07$ & 4.79E-07 & 4.85E-07 & 4.82E-07 & 3.87E-07 & 3.13E-07 & $1.26 \mathrm{E}-07$ & $5.78 \mathrm{E}-08$ \\
\hline SSE & $1.64 \mathrm{E}-07$ & $3.70 \mathrm{E}-07$ & 3.53E-07 & $3.70 \mathrm{E}-07$ & 4.24E-07 & $4.84 \mathrm{E}-07$ & 5.32E-07 & $5.62 \mathrm{E}-07$ & 5.75E-07 & $5.74 \mathrm{E}-07$ & 4.66E-07 & 3.79E-07 & $1.54 \mathrm{E}-07$ & 7.08E-08 \\
\hline SE & $1.18 \mathrm{E}-07$ & $2.51 \mathrm{E}-07$ & $2.30 \mathrm{E}-07$ & 2.43E-07 & 2.87E-07 & 3.36E-07 & 3.77E-07 & 4.05E-07 & 4.19E-07 & $4.22 \mathrm{E}-07$ & $3.50 \mathrm{E}-07$ & 2.88E-07 & $1.20 \mathrm{E}-07$ & 5.55E-08 \\
\hline ESE & 7.46E-08 & $1.57 \mathrm{E}-07$ & 1.38E-07 & $1.40 \mathrm{E}-07$ & $1.62 \mathrm{E}-07$ & $1.91 \mathrm{E}-07$ & $2.18 \mathrm{E}-07$ & 2.38E-07 & $2.51 \mathrm{E}-07$ & $2.56 \mathrm{E}-07$ & $2.18 \mathrm{E}-07$ & $1.82 \mathrm{E}-07$ & 7.76E-08 & $3.62 \mathrm{E}-08$ \\
\hline E & $9.99 \mathrm{E}-08$ & $2.08 \mathrm{E}-07$ & $1.81 \mathrm{E}-07$ & $1.74 \mathrm{E}-07$ & $1.89 \mathrm{E}-07$ & 2.12E-07 & 2.33E-07 & $2.49 \mathrm{E}-07$ & 2.57E-07 & $2.59 \mathrm{E}-07$ & $2.14 \mathrm{E}-07$ & $1.75 \mathrm{E}-07$ & 7.15E-08 & $3.27 \mathrm{E}-08$ \\
\hline ENE & $2.09 \mathrm{E}-07$ & $4.12 \mathrm{E}-07$ & 3.36E-07 & $2.94 \mathrm{E}-07$ & $2.90 \mathrm{E}-07$ & $3.04 \mathrm{E}-07$ & $3.19 \mathrm{E}-07$ & $3.29 \mathrm{E}-07$ & 3.33E-07 & $3.30 \mathrm{E}-07$ & 2.63E-07 & $2.11 \mathrm{E}-07$ & $8.29 \mathrm{E}-08$ & $3.74 \mathrm{E}-08$ \\
\hline $\mathrm{NE}$ & 3.52E-07 & $6.86 \mathrm{E}-07$ & $5.54 \mathrm{E}-07$ & 4.74E-07 & 4.56E-07 & 4.64E-07 & 4.79E-07 & 4.87E-07 & 4.87E-07 & $4.80 \mathrm{E}-07$ & 3.77E-07 & $3.00 \mathrm{E}-07$ & 1.17E-07 & 5.26E-08 \\
\hline NNE & $3.25 \mathrm{E}-07$ & $6.38 \mathrm{E}-07$ & 5.26E-07 & $4.62 \mathrm{E}-07$ & 4.53E-07 & 4.67E-07 & 4.85E-07 & 4.95E-07 & 4.97E-07 & $4.90 \mathrm{E}-07$ & 3.87E-07 & $3.10 \mathrm{E}-07$ & $1.23 \mathrm{E}-07$ & $5.58 \mathrm{E}-08$ \\
\hline
\end{tabular}


Table B.3. Chi/Q $\left(\mathrm{sec} / \mathrm{m}^{3}\right)$ for 3430 Building Stack Parameters - Effective Stack Height with Buoyant and Momentum Plume Rise

\begin{tabular}{|c|c|c|c|c|c|c|c|c|c|c|c|c|c|c|}
\hline \multirow[b]{2}{*}{ Direction } & \multicolumn{14}{|c|}{ Distance (meters) } \\
\hline & 100 & 200 & 300 & 400 & 500 & 600 & 700 & 800 & 900 & 1000 & 1500 & 2000 & 5000 & 10000 \\
\hline $\mathrm{N}$ & $4.35 \mathrm{E}-07$ & $5.68 \mathrm{E}-07$ & 4.89E-07 & 4.97E-07 & $5.45 \mathrm{E}-07$ & 5.94E-07 & $6.23 \mathrm{E}-07$ & $6.31 \mathrm{E}-07$ & $6.23 \mathrm{E}-07$ & 6.07E-07 & $4.74 \mathrm{E}-07$ & $3.80 \mathrm{E}-07$ & $1.48 \mathrm{E}-07$ & $6.74 \mathrm{E}-08$ \\
\hline NNW & $4.70 \mathrm{E}-07$ & $6.21 \mathrm{E}-07$ & 5.30E-07 & 5.27E-07 & 5.67E-07 & $6.08 \mathrm{E}-07$ & 6.31E-07 & 6.35E-07 & $6.26 \mathrm{E}-07$ & 6.09E-07 & 4.79E-07 & 3.89E-07 & $1.56 \mathrm{E}-07$ & $7.21 \mathrm{E}-08$ \\
\hline NW & 7.94E-07 & $1.02 \mathrm{E}-06$ & 8.41E-07 & 7.97E-07 & 8.20E-07 & 8.51E-07 & 8.65E-07 & $8.58 \mathrm{E}-07$ & 8.37E-07 & 8.09E-07 & $6.29 \mathrm{E}-07$ & 5.09E-07 & 2.04E-07 & 9.49E-08 \\
\hline WNW & 7.87E-07 & $9.59 \mathrm{E}-07$ & 7.53E-07 & 6.83E-07 & $6.74 \mathrm{E}-07$ & 6.77E-07 & $6.71 \mathrm{E}-07$ & 6.53E-07 & $6.28 \mathrm{E}-07$ & 5.99E-07 & 4.46E-07 & 3.49E-07 & 1.32E-07 & 5.97E-08 \\
\hline W & 7.34E-07 & 8.78E-07 & $6.50 \mathrm{E}-07$ & 5.35E-07 & 4.77E-07 & $4.40 \mathrm{E}-07$ & 4.08E-07 & 3.78E-07 & 3.49E-07 & 3.22E-07 & 2.18E-07 & $1.61 \mathrm{E}-07$ & $5.40 \mathrm{E}-08$ & 2.35E-08 \\
\hline WSW & 6.07E-07 & $7.21 \mathrm{E}-07$ & 5.35E-07 & 4.35E-07 & $3.80 \mathrm{E}-07$ & 3.43E-07 & 3.12E-07 & 2.84E-07 & 2.59E-07 & 2.36E-07 & $1.54 \mathrm{E}-07$ & $1.10 \mathrm{E}-07$ & 3.52E-08 & $1.50 \mathrm{E}-08$ \\
\hline SW & $6.23 \mathrm{E}-07$ & $7.40 \mathrm{E}-07$ & 5.49E-07 & 4.47E-07 & 3.92E-07 & 3.54E-07 & 3.22E-07 & $2.94 \mathrm{E}-07$ & 2.68E-07 & 2.45E-07 & $1.62 \mathrm{E}-07$ & 1.17E-07 & 3.85E-08 & $1.66 \mathrm{E}-08$ \\
\hline SSW & $6.26 \mathrm{E}-07$ & 7.79E-07 & $6.01 \mathrm{E}-07$ & $5.18 \mathrm{E}-07$ & 4.84E-07 & 4.63E-07 & 4.43E-07 & 4.19E-07 & 3.93E-07 & $3.68 \mathrm{E}-07$ & $2.58 \mathrm{E}-07$ & $1.94 \mathrm{E}-07$ & $6.78 \mathrm{E}-08$ & 2.98E-08 \\
\hline S & 4.47E-07 & 6.19E-07 & 5.57E-07 & 5.82E-07 & 6.37E-07 & 6.83E-07 & 7.04E-07 & 7.01E-07 & 6.84E-07 & 6.59E-07 & 4.96E-07 & 3.87E-07 & $1.44 \mathrm{E}-07$ & $6.48 \mathrm{E}-08$ \\
\hline SSE & 3.45E-07 & 5.18E-07 & $5.24 \mathrm{E}-07$ & $6.15 \mathrm{E}-07$ & 7.18E-07 & 7.93E-07 & 8.30E-07 & 8.34E-07 & 8.17E-07 & 7.89E-07 & 5.99E-07 & 4.70E-07 & 1.77E-07 & 7.94E-08 \\
\hline SE & 2.47E-07 & 3.44E-07 & 3.43E-07 & 4.15E-07 & $5.00 \mathrm{E}-07$ & $5.65 \mathrm{E}-07$ & $6.02 \mathrm{E}-07$ & 6.12E-07 & $6.05 \mathrm{E}-07$ & 5.89E-07 & 4.55E-07 & $3.61 \mathrm{E}-07$ & $1.38 \mathrm{E}-07$ & $6.24 \mathrm{E}-08$ \\
\hline ESE & $1.56 \mathrm{E}-07$ & 2.13E-07 & $2.00 \mathrm{E}-07$ & 2.34E-07 & 2.84E-07 & 3.29E-07 & 3.57E-07 & 3.69E-07 & 3.69E-07 & 3.63E-07 & 2.87E-07 & 2.30E-07 & 8.96E-08 & 4.07E-08 \\
\hline E & 2.08E-07 & 2.81E-07 & $2.54 \mathrm{E}-07$ & 2.75E-07 & 3.14E-07 & 3.49E-07 & 3.69E-07 & 3.75E-07 & 3.71E-07 & 3.60E-07 & 2.76E-07 & 2.18E-07 & 8.15E-08 & 3.64E-08 \\
\hline ENE & 4.33E-07 & $5.44 \mathrm{E}-07$ & 4.42E-07 & 4.27E-07 & 4.48E-07 & 4.72E-07 & 4.83E-07 & 4.80E-07 & 4.67E-07 & 4.49E-07 & 3.34E-07 & 2.58E-07 & $9.38 \mathrm{E}-08$ & 4.13E-08 \\
\hline $\mathrm{NE}$ & 7.28E-07 & 9.03E-07 & 7.20E-07 & 6.72E-07 & 6.84E-07 & 7.05E-07 & 7.11E-07 & 7.00E-07 & 6.77E-07 & 6.47E-07 & 4.77E-07 & 3.66E-07 & $1.32 \mathrm{E}-07$ & $5.80 \mathrm{E}-08$ \\
\hline NNE & 6.72E-07 & 8.45E-07 & 6.95E-07 & $6.66 \mathrm{E}-07$ & $6.89 \mathrm{E}-07$ & 7.15E-07 & 7.24E-07 & 7.14E-07 & $6.92 \mathrm{E}-07$ & 6.63E-07 & 4.92E-07 & 3.82E-07 & $1.40 \mathrm{E}-07$ & $6.18 \mathrm{E}-08$ \\
\hline
\end{tabular}




\section{Distribution}

No. of

Copies

ONSITE

20 Pacific Northwest National Laboratory

C. M. Andersen K1-38

J. M. Barnett J2-25

J. H. Brown J2-25

R. J. Colley J2-19

E. G. Damberg J2-25

C. J. Duchsherer J2-25

D. L. Edwards J2-25

B. G. Fritz K6-75

J. A. Glissmeyer K3-54

M. L. Johnson K3-54

K. M. Meier K3-52

C. J. Nichols J2-53

B. E. Opitz K6-75

T. M. Poston K6-75

K. Rhoads K3-54

R. D. Sharp J2-33

S. F. Snyder K3-54

M. J. Stephenson J2-25

H. R. Vogel J2-19

Hanford Technical Library P8-55 



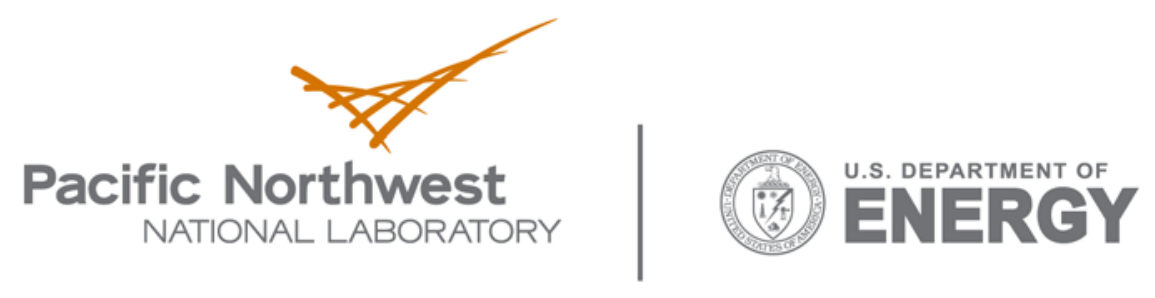

902 Battelle Boulevard

P.O. Box 999

Richland, WA 99352

1-888-375-PNNL (7665)

www.pnl.gov 